\title{
Novitates
}

PUBLISHED BY THE AMERICAN MUSEUM OF NATURAL HISTORY CENTRAL PARK WEST AT 79TH STREET, NEW YORK, NY 10024

Number 3497, 31 pp., 10 figures, 5 tables November 29, 2005

\section{Description of a New Genus and Species of Rodent (Murinae, Muridae, Rodentia) from the Khammouan Limestone National Biodiversity Conservation Area in Lao PDR}

\author{
GUY G. MUSSER, ${ }^{1}$ ANGELA L. SMITH, ${ }^{2}$ M. F. ROBINSON,${ }^{3}$ AND \\ DARRIN P. LUNDE ${ }^{4}$
}

\begin{abstract}
Saxatilomys paulinae, a new genus and species of murid rodent in the Dacnomys Division is described. It is based on two whole specimens and 14 individuals represented by fragments recovered from owl pellets. The samples come from the Khammouan Limestone National Biodiversity Conservation Area in Khammouan Province in central Lao PDR. This tower karst landscape is part of the Quy Dat limestone massif, which extends eastward into north-central Vietnam (Binh Tri Thien Province). The new genus and species is morphologically (and probably phylogenetically) allied to species of Niviventer and Chiromyscus, which are also members of the Dacnomys Division, but its semispinous dark gray upperparts, dark frosted gray underparts, large, extremely bulbous footpads, and a combination of derived and primitive cranial and dental traits exclude it from membership in Niviventer, Chiromyscus, or any other described genus of Indo-malayan murid. The new species is likely petricolous, and is part of a small but unique community of small nonvolant mammals containing the petricolous gymnure, Hylomys megalotis, and hystricognath, Laonastes aenigmamus. All three species have been collected only in forested, rocky habitats of the Khammouan Limestone, but comparable environments in the adjacent Vietnamese portion of the Quy Dat limestone massif may harbor these same species specialized for living in forested, karstic landscapes.
\end{abstract}

${ }^{1}$ Division of Vertebrate Zoology (Mammalogy), American Museum of Natural History. Current address: 1714 Henley Lane, Charleston, SC 29412 (holdenmusser@comcast.net).

24 Layton Avenue, Malvern, Worcestershire, WR14 2ND, United Kingdom.

${ }^{3}$ WWF Thailand Programme Office, Bangkok, Thailand.

${ }^{4}$ Division of Vertebrate Zoology (Mammalogy), American Museum of Natural History (lunde@amnh.org). 


\section{INTRODUCTION}

The Quy Dat massif, an extensive and spectacular tower karst landscape, geologically derived from ancient sedimentation in Late Carboniferous seas, straddles north-central Vietnam (in Binh Tri Thien Province), and central Lao Peoples Democratic Republic (PDR), in Khammouan Province (Fontaine and Workman, 1978, 1997). The Lao PDR portion is the site of the Khammouan Limestone National Biodiversity Conservation Area (NBCA) (Robinson and Webber, 1998). The Khamouan Limestone was one of 18 regions formally declared a National Biodiversity Conservation Area in October,
1993, along with an additional 11 recommended areas. Covering 1590 square kilometers, the NBCA is comprised of primarily tower karst topography, with a dry open xerophytic flora on the limestone and small pockets of mixed tropical moist deciduous and tropical lowland evergreen rain forest (terminology follows Whitmore, 1984) in valleys and low-lying places (figs. 1, 2). Within the region settlements are established over most of the flat lowlands, and the land cleared by local residents for paddy cultivation and shifting agriculture; however, such places are excluded from the NBCA (Berkmuller et al., 1995). Villagers also collect

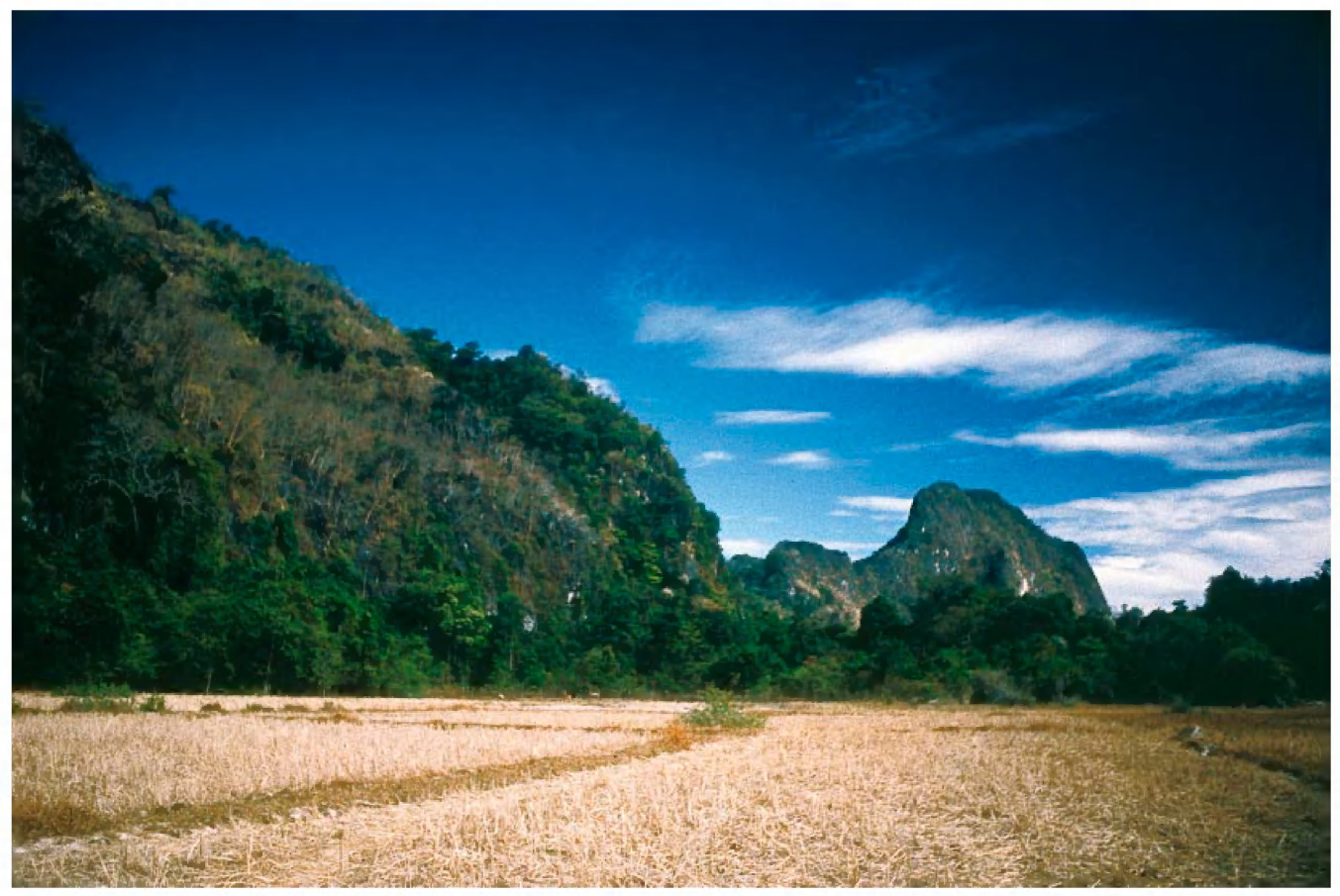

Fig. 1. The limestone within $1 \mathrm{~km}$ of Ban (= village) Mauang and Ban Doy $\left(17^{\circ} 33^{\prime} 15^{\prime \prime} \mathrm{N} / 104^{\circ}\right.$ $49^{\prime} 30^{\prime \prime} \mathrm{E}$ ), Thakhet District, in the southwest of the Khammouan Limestone National Biodiversity Conservation Area (NBCA), Lao PDR, approximately $18 \mathrm{~km}$ north of the town of Thakhek (see fig. $4 \mathrm{map}$ ). The whole examples of Saxatilomys paulinae were trapped at the base of the massive karst. Paddy rice covers the adjacent flat. Photographed by M. F. Robinson.

Fig. 2. Heavily degraded deciduous forest mixed with scrub and bamboo at the base of the karst where the two whole specimens of Saxatilomys paulinae were collected. Photographed by M. F. Robinson. 


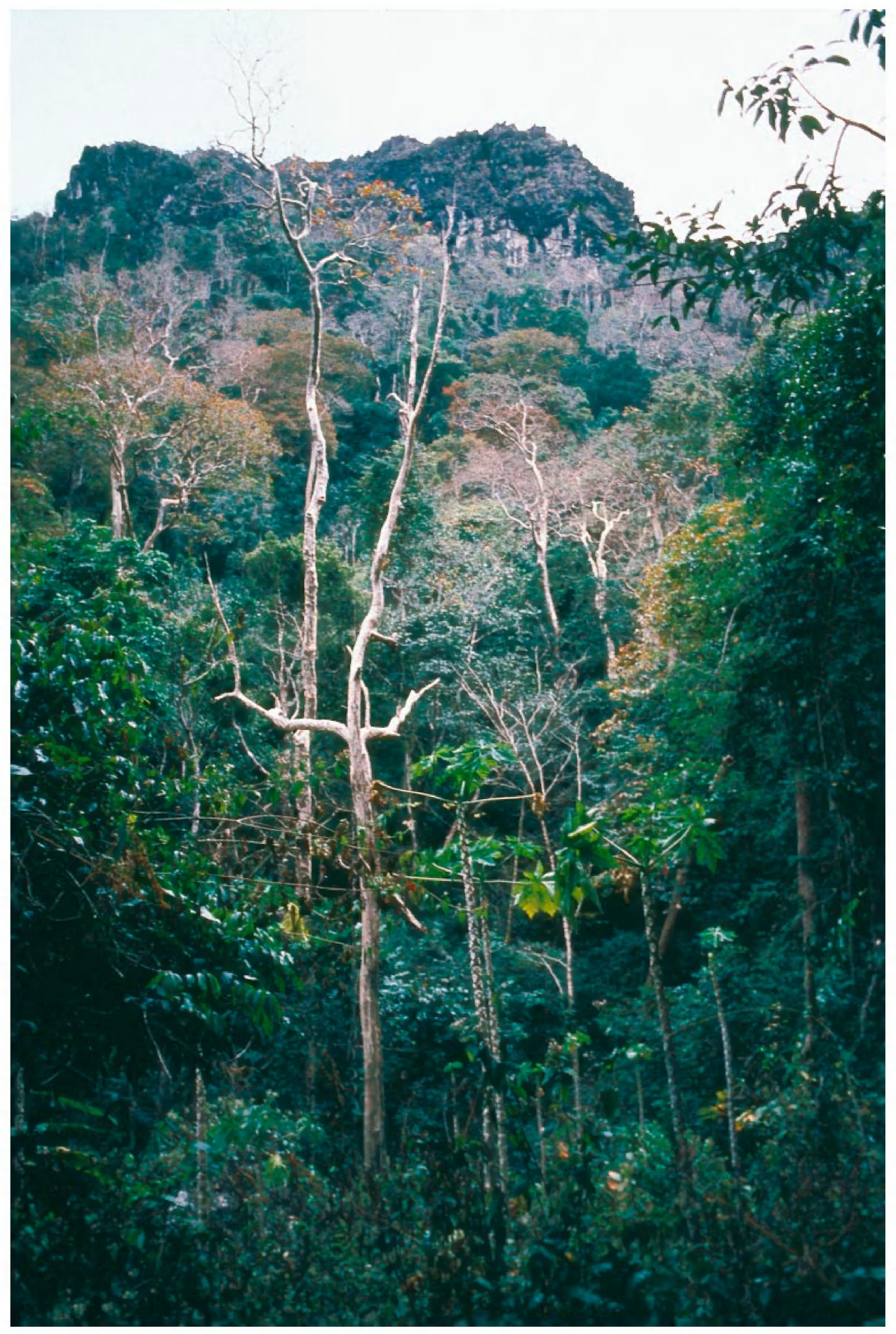


forest products and hunting is widespread. Within the protected area there is little surface water and riverine systems are scanty. Highest elevation is $1578 \mathrm{~m}$ (above sea level), but $95 \%$ of the area falls between 200 and $500 \mathrm{~m}$ (Berkmuller et al., 1995).

Surveys in the NBCA during 1998 and 1999 focusing on small mammals (Robinson and Webber, 1998, 1999) have yielded abundant samples of shrews (Smith et al., 1998), bats (Robinson and Webber, 2000), and rodents (Smith et al., 2004). The material collected also contained examples of three new taxa now known to occur only in the Khammouan Limestone region: new species of bat, Hipposideros scutinares (Robinson et al., 2003), and gymnure, Hylomys megalotis (Jenkins and Robinson, 2002); and a new family, genus, and species of hystricognath, Laonastes aenigmamus (Laonastidae) (Jenkins et al., 2005).

A fourth discovery is a new genus and species of murid rodent represented by two medium-sized gray rats, and skeletal and dental fragments of 14 other individuals that were recovered from owl pellets. The samples were obtained during a biodiversity survey of the NBCA in 1999. This unique animal is the subject of the present report.

\section{ABBREVIATIONS, METHODS, AND MATERIAL}

InSTITUTIONS: Specimens we studied are stored in collections of the American Museum of Natural History, New York (AMNH); Natural History Museum, London (BMNH); Field Museum of Natural History, Chicago (FMNH); Hokkaido University Natural History Museum, Sapporo (HUNHM); Zoological Museum, Institute for Ecology and Biological Resources, Hanoi (IEBR); Museum National d'Histoire Naturelle, Paris (MNHN); Rijksmuseum van Natuurlijke Historie, Leiden [now Nationaal Natuurhistorisch Museum, Leiden] (RMNH); National Museum of Natural History, Smithsonian Institution, Washington, DC (USNM); and Zoologisches Forschungsinstitut und Museum Alexander Koenig, Bonn (ZFMK). The acronyms preface catalog numbers referring to specimens cited throughout the report and in the appendix.
SPECIMENS: The two whole examples of the new rat were preserved in $5 \%$ formalin for 4 to 5 days and subsequently transferred to a $70 \%$ ethanol solution for permanent storage. Nearly all of the comparative material consists of standard museum preparations: a stuffed skin and accompanying cranium and mandible. A few samples were preserved in formalin when collected and are currently stored in a $70 \%$ ethanol solution; we studied their external features and from some of them we extracted skulls and cleaned them.

Values (in millimeters) for total length, length of tail (LT), length of hind foot, including claw (LHF), and length of ear from intertragal notch to crown (LE) were obtained by Musser from the preserved intact specimens. He also measured the following cranial and dental dimensions using digital calipers accurate to the nearest $0.1 \mathrm{~mm}$. The dimensions are listed in the sequence they appear in tables; their limits are illustrated in figure 3 and defined in Musser and Newcomb (1983) and Musser and Durden (2002).

$\begin{array}{ll}\text { ONL } & \begin{array}{l}\text { occipitonasal length (= greatest length } \\ \text { of skull) }\end{array} \\ \text { ZB } & \begin{array}{l}\text { zygomatic breadth } \\ \text { IBterorbital breadth }\end{array} \\ \text { LR } & \begin{array}{l}\text { length of rostrum } \\ \text { breadth of rostrum }\end{array} \\ \text { BBC } & \begin{array}{l}\text { breadth of braincase } \\ \text { HBC }\end{array} \\ \text { height of braincase } \\ \text { BZP } & \text { breadth of zygomatic plate } \\ \text { LD } & \text { length of diastema } \\ \text { LIF } & \begin{array}{l}\text { length of incisive foramina } \\ \text { BIF }\end{array} \\ \text { breadth of incisive foramina } \\ \text { BBP } & \begin{array}{l}\text { length of bony palate (palatal bridge) } \\ \text { breadth across bony palate at first mo- }\end{array} \\ \text { PPL } & \begin{array}{l}\text { lars } \\ \text { postpalatal length }\end{array} \\ \text { BMF } & \text { breadth of mesopterygoid fossa } \\ \text { LB } & \text { length of bulla } \\ \text { CLM1-3 } & \begin{array}{l}\text { crown length of maxillary molar row } \\ \text { bM1 }\end{array} \\ \text { bLm1-3 } & \begin{array}{l}\text { crown length of mandibular molar row } \\ \text { breadth of first lower (mandibular) mo- }\end{array} \\ \text { Bm1 } & \text { lar }\end{array}$

Old adults, adults, and young adults (as defined by Musser and Heaney, 1992: 5) were lumped together as "adults" and measurements derived from them were used to calculate standard descriptive statistics (mean, standard deviation, and observed range). Sexes were combined in the analyses. 

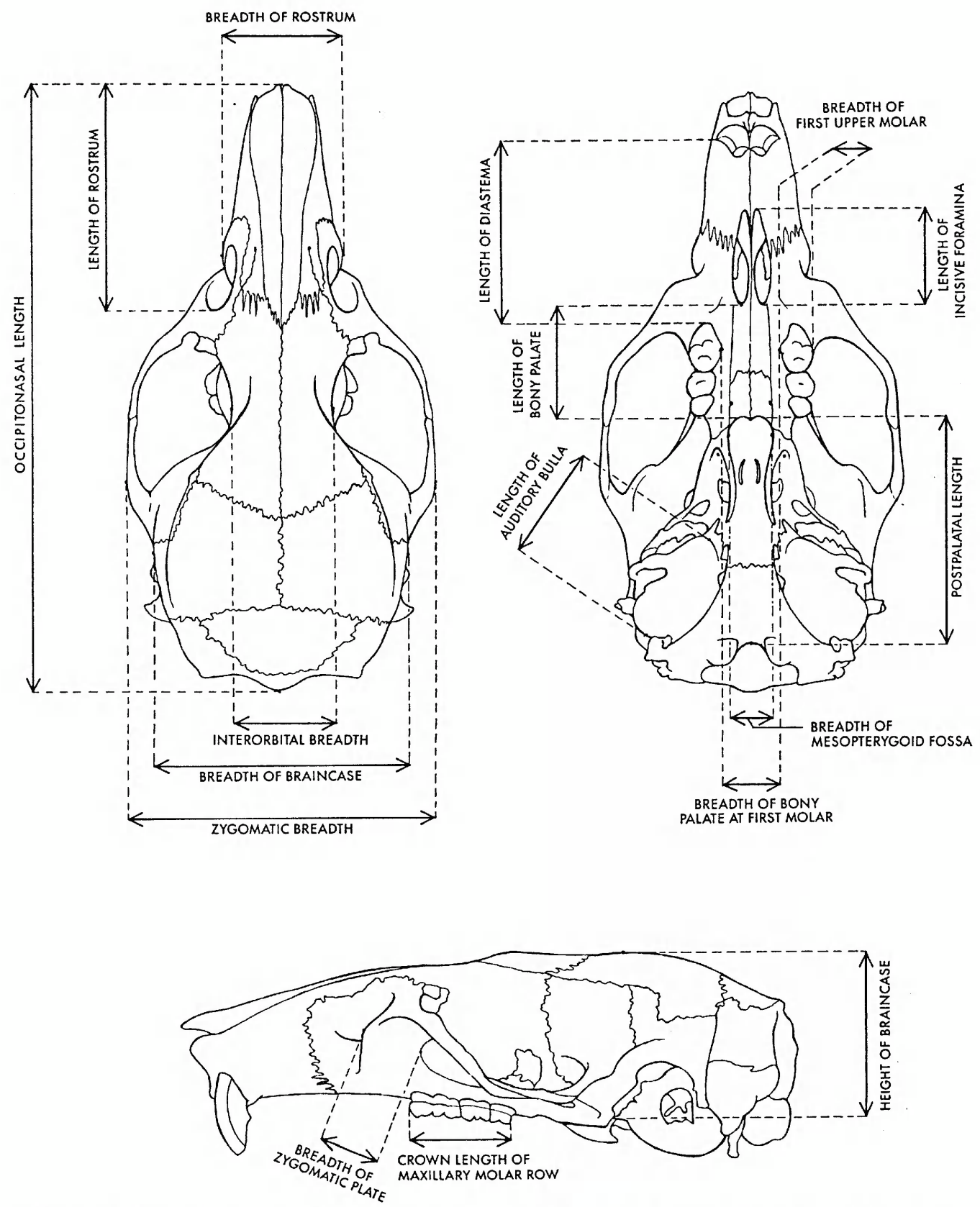

Fig. 3. Views of an adult Bunomys chrysocomus showing limits most of cranial and dental measurements. See text for additional information. Not shown: BIF (greatest breath across incisive foramina), Clm-3 (from face of first lower molar to posterior margin of third molar), and bml (greatest breadth across first lower molar); see p. 4. 
Anatomical terminology follows Brown (1971) and Brown and Yalden (1973) for external features of the head and limbs; Bugge (1970) for the cephalic arteries; Wahlert (1985) for the cranial foramina; and Carleton (1980), Carleton and Musser (1984), Musser and Durden (2002), Musser and Heaney (1992), Musser et al. (1998), and Voss (1988) for cranial morphology. Names of cusps and cusplets of upper (maxillary) and lower (mandibular) molars are noted in figure 9.

\section{SYSTEMATIC DESCRIPTION OF THE NEW GENUS AND SPECIES}

\section{Saxatilomys, new genus}

TyPE SPECIES: Saxatilomys paulinae, the new species described below.

Diagnosis: A genus of Muridae in the Dacnomys Division (Musser and Carleton, 2005) of the subfamily Murinae (as delimited by Carleton and Musser, 1984) that is set apart from all other described murid genera by the following combination of morphological traits: (1) fur covering head and body thick, semispinous, and dark gray with burnished highlights, underparts dark grayish white unbroken by any white patches, ears grayish brown; (2) dorsal surfaces of front and hind feet brownish gray; (3) tail appreciably longer than length of head and body, thin and tapered, round in cross section, dorsal and lateral sides dark brown from base to tip, ventral surface white but lightly speckled with brown from the pigmented tail bristles; (4) palmar and plantar pads large, extremely bulbous, and set close together; (5) four pairs of mammae; (6) gracile skull with narrow (relative to broad braincase) and moderately long rostrum, wide zygomatic plate, prominent postorbital and temporal ridges, wide and low braincase, and deep occiput; (7) squamosal root of each zygomatic arch situated high on the side of the cranium where it extends as a ridge diagonally to merge with the temporal ridge well anterior to the vertical squamosal-exoccipital suture (the parietal does not project ventrad to form part of the lateral braincase wall); (8) lateral cranial wall intact anterior to occiput, without large subsquamosal foramen; (9) alisphenoid struts in most specimens; (10) long and narrow incisive foramina, their posterior borders lo- cated just before anterior margins of molar rows or penetrating slightly between them; (11) maxillary molar rows that are long relative to skull length and that diverge appreciably from anterior to posterior margins (along the anteroposterior axis); (12) wide and long bony palate projecting beyond molar rows to form narrow platform with smooth posterior margin; (13) moderately spacious sphenopalatine vacuities; (14) wide and shallowly excavated pterygoid fossae; (15) small ectotympanic bulla relative to skull size, concealing most of periotic, so slanting posterodorsal wall of carotid canal formed by ectotympanic and not periotic; (16) large stapedial artery and no sphenofrontal foramen or squamosoalisphenoid groove, indicators of a cephalic arterial pattern that is widespread among murines; (17) coronoid process of dentary small, condyloid and angular processes joined by moderately deeply concave posterior margin of dentary, and alveolar incisor capsule only slightly evident on lateral dentary surface; (18) upper incisors opisthodont relative to rostrum; (19) first upper (maxillary) molar with five roots (anterior, posterior, two lingual, and single labial); (20) each lower (mandibular) molar with two roots (anterior and posterior); (21) molars brachydont, with cusp rows forming uncomplicated occlusal patterns resembling those in most species of Niviventer; and (22) anterolabial cusps prominent on second and third lower molars.

ETymology: We combine the Latin, saxatilis, meaning "among the rocks", with the Greek mys for mouse (or rat).

\section{Saxatilomys paulinae, new species}

Holotype: BMNH 2000.292; fluid-preserved whole body, with the skull removed and cleaned, of an adult male (original number 11/99) caught by local villagers on January 16, 1999, and given to Mark F. Robinson. Standard external, cranial, and dental measurements, along with other data, are listed in table 1 . The animal was originally fixed in $5 \%$ formalin for 4 to 5 days and subsequently transferred to a $70 \%$ ethanol solution. The skull was extracted, cleaned, and is intact (fig. 6).

TyPE Locality: Trapped within $1 \mathrm{~km}$ of 


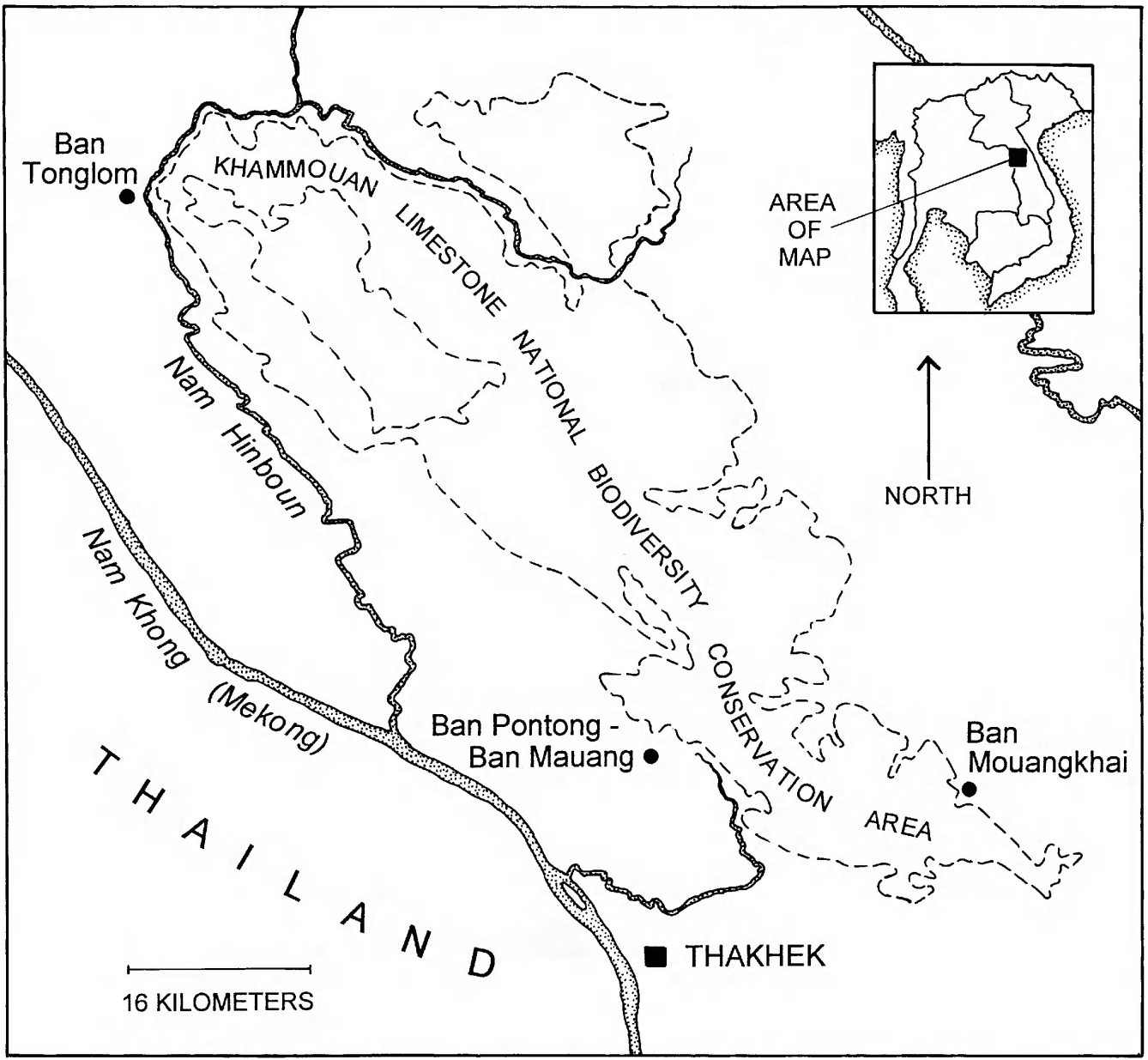

Fig. 4. Collection sites of Saxatilomys paulinae in the Khamouan Limestone NBCA, Lao PDR. The two whole examples were collected near Ban Mauang. Tam Jungvung is close by, where owl pellets were found containing fragments of $S$. paulinae. Skeletal and dental pieces of the species were also recovered from Tam En, near Ban Tonglom, and Tam Key Thea, in the vicinity of Ban Mouangkhai.

Ban (= village) Mauang and Ban Doy (17 $\left.33^{\prime} 15^{\prime \prime} \mathrm{N} / 104^{\circ} 49^{\prime} 30^{\prime \prime} \mathrm{E}\right)$, Thakhet District, on the southwest margin of the Khammouan Limestone National Biodiversity Conservation Area $\left(17^{\circ} 26^{\prime}-18^{\circ} 05^{\prime} \mathrm{N} / 104^{\circ} 25^{\prime}-105^{\circ} 10^{\prime} \mathrm{E}\right)$, Lao PDR, approximately $18 \mathrm{~km}$ north of the town of Thakhek (see fig. 4 map). The species is known locally as nou noi (nou = rat, $n o i=$ little/small).

REFERRED MATERIAL: Fifteen specimens. A young adult female (AMNH 272953) trapped at the type locality on January 15, 1999. The animal was originally fixed in 5\% formalin for 4 to 5 days and then transferred to a $70 \%$ ethanol and water mixture. The skull has been extracted and cleaned and is undamaged.

Fourteen individuals were obtained during January and February, 1998, and are represented by cranial, mandibular, and dental fragments recovered from owl pellets gathered in the following three caves (tam = cave), all in Khammouan Province, Lao PDR (tables 2, 3): Tam Jungvung $\left(17^{\circ} 33^{\prime} 40^{\prime \prime} \mathrm{N} /\right.$ 
TABLE 1

Age, Sex, Cranial and Dental Measurements ( $\mathrm{mm})$, and Other Data from the Two Whole Examples of Saxatilomys paulinae from the Vicinity of Ban Mauang and Ban Doy, Central Lao PDR

\begin{tabular}{lcc}
\hline \hline & BMNH 2000.292 (holotype) & AMNH 272953 \\
\hline Age & adult & young adult \\
Sex & male & female \\
Length of head and body & 150 & 144 \\
Length of tail & 168 & 167 \\
LT/LHB (\%) & 112 & 116 \\
Length of hind foot & 32 & 32 \\
Length of ear & 25 & 24 \\
Occipitonasal length & 40.5 & 40.3 \\
Zygomatic breadth & 18.0 & 17.7 \\
Interorbital breadth & 5.8 & 6.0 \\
Length of rostrum & 13.5 & 13.5 \\
Breadth of rostrum & 6.0 & 5.9 \\
Breadth of braincase & 15.8 & 16.7 \\
Height of braincase & 10.3 & 11.0 \\
Breadth of zygomatic plate & 4.1 & 4.0 \\
Length of diastema & 10.5 & 9.9 \\
Length of incisive foramina & 6.7 & 7.2 \\
Breadth of incisive foramina & 2.1 & 2.5 \\
Length of bony palate & 8.7 & 8.4 \\
Breadth across bony palate at M1 & 3.6 & 3.2 \\
Postpalatal length & 12.8 & 12.2 \\
Breadth of mesopterygoid fossa & 2.7 & 2.8 \\
Length of bulla & 5.5 & 5.2 \\
Crown length of M1-3 & 7.3 & 7.3 \\
Breadth of M1 & 2.0 & 2.1 \\
Crown length of m1-3 & 7.1 & 7.2 \\
Breadth of m1 & 2.0 & 2.0 \\
\hline & & \\
& & \\
& &
\end{tabular}

$\left.104^{\circ} 50^{\prime} 15^{\prime \prime} \mathrm{E}\right), 200 \mathrm{~m}$, a cave system near Ban Mauang and Ban Doy $\left(17^{\circ} 33^{\prime} 25^{\prime \prime} \mathrm{N} / 104^{\circ}\right.$ $49^{\prime} 35^{\prime \prime} \mathrm{E}$ ) on the southwest margin of the NBCA, Thakhek District, approximately 18 $\mathrm{km}$ north of the town of Thakhek: AMNH 272920, 272921. Tam En ("Swift Cave") $\left(18^{\circ} 01^{\prime} 40^{\prime \prime} \mathrm{N} / 104^{\circ} 25^{\prime} 50^{\prime \prime} \mathrm{E}\right)$, about $67 \mathrm{~km}$ northwest of Tam Jungvung and Mauang and Doy villages, $300 \mathrm{~m}$, an extensive cave system $2.5 \mathrm{~km}$ northeast along the River Hinboun from Ban Tonglom, Hinboun District: AMNH 272914-272919; BMNH 2000.2882000.290, 2000.695, 2000.696. Tam Key Thea ("Bat Guano Cave") (17 $32^{\prime} 50^{\prime \prime N} /$ $\left.105^{\circ} 03^{\prime} 50^{\prime \prime} \mathrm{E}\right), 100 \mathrm{~m}, 2 \mathrm{~km}$ north of Ban Mouangkhai (formerly called Ban Tat) in Gnommalat District, and on the southeast boundary of the NBCA: BMNH 2000.291.

GeOGRAPHIC Distribution: Known only from the four localities listed above, all in the Khammouan Limestone NBCA in central Lao PDR. This tower karst landscape, a product of mostly ancient sedimentation in Carboniferous seas and subsequent lithification, is part of the Quy Dat massif, which outcrops at the same latitude in Binh Tri Thien Province of north-central Vietnam (Fontaine and Workman, 1978, 1997; Tuyet, 1998). Providing that adequate forest cover is still extant, we would expect to find $S$. paulinae living in suitable limestone habitats in that part of Vietnam, perhaps along with the terrestrial gymnure, Hylomys megalotis, and the hystricognath, Laonastes aenigmamus, at present known only from the Khammouan Limestone (Jenkins and Robinson, 2002; Jenkins et al., 2005).

Diagnosis: Because paulinae is the only known species of Saxatilomys, generic and specific diagnoses are the same. 
TABLE 2

Measurements (mm) of Maxillary and Mandibular Molars from Saxatilomys paulinae (Young to old adult cranial and mandibular fragments or isolated molars extracted from owl pellets.)

\begin{tabular}{lcccc}
\hline \hline \multirow{2}{*}{$\begin{array}{c}\text { Village and } \\
\text { specimen }\end{array}$} & \multicolumn{5}{c}{ Length and breadth } \\
\cline { 2 - 5 } Tam Jungvung \\
AMNH 272921 & CLM1-3 & BM1 & CLm1-3 & Bm1 \\
AMNH 272920 & 7.2 & 2.1 & - & - \\
Tam En & & & 7.2 & 2.0 \\
AMNH 272918 & - & - & 7.1 & 1.8 \\
BMNH 2000.288 & - & - & 7.1 & 2.1 \\
AMNH 272916 & - & - & - & 2.0 \\
AMNH 272919 & - & - & - & 1.9 \\
BMNH 2000.695 & - & - & - & 2.0 \\
BMNH 2000.696 & - & & & \\
\hline
\end{tabular}

ETymology: During frequent and lengthy visits to the Natural History Museum in London over three decades, Musser (and probably other visitors) has forgotten how many times he sat on the front steps of that historical and hallowed building waiting for the guardians of the mammal collections to arrive and escort him in. But he has never forgotten the cheery morning greeting when Paula Jenkins arrived, the walk together to the office for the great ring of keys, and her courteous efforts to install him in storage

TABLE 3

The Fragmentary Specimens of Saxatilomys paulinae Extracted from Owl Pellets (Measurements of some molar rows and isolated teeth are listed in table 2.)

\begin{tabular}{|c|c|c|}
\hline $\begin{array}{l}\text { Village and } \\
\text { specimen }\end{array}$ & Age & Description \\
\hline \multicolumn{3}{|l|}{ Tam Jungvung } \\
\hline AMNH 272921 & adult & $\begin{array}{l}\text { right part of cranium with orbit, zygomatic plate, } \\
\text { rostrum with incisor, and intact molar row }\end{array}$ \\
\hline AMNH 272920 & adult & left dentary with intact molar row \\
\hline \multicolumn{3}{|l|}{ Tam Key Thea } \\
\hline BMNH 2000.291 & young adult & $\begin{array}{l}\text { right maxillary fragment containing second and } \\
\text { third molars }\end{array}$ \\
\hline \multicolumn{3}{|l|}{ Tam En } \\
\hline BMNH 2000.290 & young adult & right maxillary fragment with second molar \\
\hline AMNH 272918 & young adult & left dentary with all three molars \\
\hline BMNH 2000.288 & adult & right dentary with intact row of molars \\
\hline AMNH 272916 & old adult & $\begin{array}{l}\text { left dentary with all three molars, side of first } \\
\text { molar eroded }\end{array}$ \\
\hline AMNH 272919 & adult & left dentary containing first and second molars \\
\hline AMNH 272914 & old adult & $\begin{array}{l}\text { left dentary with incomplete first molar and intact } \\
\text { second molar }\end{array}$ \\
\hline AMNH 272915 & old adult & right dentary containing second and third molars \\
\hline AMNH 272917 & $?$ & left dentary without molars \\
\hline BMNH 2000.289 & old adult & isolated first and second molars \\
\hline BMNH 2000.695 & adult & isolated first and second molars \\
\hline BMNH 2000.696 & adult & isolated first molar \\
\hline
\end{tabular}


rooms, making sure everything was available for another days work. We mammalian systematists have depended upon the mammal collections and library resources of the Natural History Museum for our research, and all of us came to depend upon Paula for access to the collections and for help with innumerable problems related to locating specimens, finding the critical gazetteers and maps, and searching library shelves for publications and field journals. We also remember the times when she had to unlock the door to a collection room because we had inadvertently locked ourselves in. We are extremely pleased to honor Paula Jenkins by attaching her name to this beautiful, grayfurred rat that is part of the spectacular and unique limestone landscape in central Lao PDR.

Morphological Description: The two whole specimens of $S$. paulinae form the foundation of our description. Except for variation due to age (adult and young adult), there is really little significant variation in the external, cranial, and dental traits we describe here. Study of a larger sample will test the acuteness of our observations and provide a firmer estimate of morphological variation within the species.

During the six years the two specimens have been stored in fluid, they were kept away from light sources, but some pelage discoloration has occurred, which in our experience is inevitable in rats with dark gray pelage. Black or dark brown bands on the hairs have been altered to dark tan, giving the upperparts a grayish brown cast. Robinson described the fresh specimens as being gray everywhere. We suspect the coat was darker (dark gray or grayish black) in the live rat, which is the tone in a color transparency of the holotype taken in the field before it was preserved. Variation in fur coloration certainly needs to be assessed by study of a large sample of freshly caught rats.

Details of external, cranial, and dental traits are described below.

The dense fur covering upperparts of head and body is dark gray (probably grayish black in life) with slightly burnished highlights, and consists of three types of hairs. The soft underhairs (up to $10 \mathrm{~mm}$ long) are gray for their entire length. The overfur layer (up to $15 \mathrm{~mm}$ thick) is formed by wide, flexible, and grooved spines, each pale gray for most of its length and tipped with brown or black. Scattered guard hairs project 5-10 $\mathrm{mm}$ beyond the overhairs; the basal half of each is gray, the distal half black (not dark tan). The combination of hair types and their pigmented banding patterns impart a thick and semispinous texture, and a slightly burnished, very dark gray tone to the upperparts. The dorsal pelage is less spiny along sides of the body, appears especially soft and gray over the shoulders and hips, and gradually blends into the softer and shorter (up to 8 $\mathrm{mm}$ thick) dark gray fur of the underparts. That ventral coat is formed by fine underhairs mixed with soft, wide, and grooved spines; the underhairs are dark gray for most of their lengths and unpigmented at the tips. Overall, the ventral coat is lightly frosted dark gray. The holotype has a darker venter than the other specimen because the unpigmented bands are shorter in its coat. Although paler than the dorsal pelage, no sharp demarcation exists between dorsal and ventral fur. No white patches are present on the venter in the two specimens we studied. Sides of the face and throat are also dark gray; the lips, chin, and rhinarium are unpigmented in one individual, the other has short brown hairs scattered over the upper lip and most of the rhinarium. Fur covering the lower limbs is dark gray everywhere, but shorter than that on the torso.

Eyes, relative to head area, are not especially large. Each narrow, circular, and dark brown ring around the eye is surrounded by a wider unpigmented ring. Beyond the eyes, the fur is dark gray, like the rest of the upperparts. No pattern is present resembling a facial mask.

The pinnae (external ears) are moderately large, but not disproportionately expansive relative to body size. Each is grayish brown, oval in outline, and rubbery in texture. Short brown hairs (visible only under magnification) are sparsely scattered over both outer and inner surfaces.

The usual armory of sensory hairs found in most murine species is also present in $S$. paulinae. The mystacial vibrissae are either dark brown or unpigmented, fine, and very long (up to $75 \mathrm{~mm}$ ); when laid against the 
head, the longest project up to $15 \mathrm{~mm}$ beyond the distal margin of each pinna. The longest in each pair of superciliary (or supraorbital) vibrissae (up to $60 \mathrm{~mm}$ long) barely extend past the pinna when appressed against the head. The short submental and interramal vibrissae are unpigmented. The few short (up to $25 \mathrm{~mm}$ ) genal vibrissae are inconspicuous and unpigmented for most of their lengths. The base of the wrist supports four moderately long (up to $10 \mathrm{~mm}$ ) unpigmented ulnar carpal vibrissae, and from the inside of each heel springs a longer (up to $15 \mathrm{~mm}$ ) unpigmented tarsal vibrissa.

The slim, tapered tail is appreciably longer than length of head and body (table 1) and round in cross-section. Dorsal and lateral surfaces are dark brown (produced by the brown pigment in scales and the bristles emerging from them); the ventral surface is unpigmented, but slightly speckled from the brown scale hairs. Scales in the overlapping annuli are small (12 and 13 rings of scales per centimeter in the two specimens, counted along basal one-third of the tail), and from beneath each scale emerge three hairs. These are bristlelike and about as long as two scale annuli $(1.0 \mathrm{~mm})$ near the base of the tail, but those at the tail tip are softer and longer (up to 3 $\mathrm{mm}$ ); there is a gradual increase in length of hairs, along with a change in texture, from base to tail tip.

Claws of the front feet are pale brown, those on the hind feet are unpigmented. Both front and hind claws are moderately long, gently curved, and their dorsal surfaces covered by tufts of thin, silver hairs (ungual tufts) that do not project beyond the claw tips. Dorsal metacarpal and metatarsal surfaces are brownish, a tone imparted by brown hairs covering these surfaces and pale brown speckling in the integument. Digits are mostly unpigmented with slight brown speckling; digital pads are pale brown. Each palmar surface is naked, and covered with five huge and swollen pads: three interdigitals, thenar, and hypothenar, all pale brown over their ventral surfaces. The hind foot is moderately long and narrow. Its naked plantar surface is gray, and the pads are surfaced with pale brown. The anterior half of the plantar area is formed by six very large and extremely bulbous pads in a tight cluster: two inner interdigitals, two outer interdigitals nearly opposite each other, a large hypothenar just behind and slightly overlapping the lateral interdigital, and an even larger thenar (fig. 5). Size of the pads relative to plantar surface, their swollen conformation, and contiguous positions resemble the configuration seen in arboreal murines like the Sulawesian species of Margaretamys (Musser, 1981: 279), but not in such terrestrial examples as Sundanese Sundamys muelleri and Berlymys bowersii (Musser and Newcomb, 1983: 357), Rattus argentiventer (Musser, 1973: 7), or Sulawesian Maxomys (Musser, 1991: 27) where the pads are much smaller relative to area of the plantar surface, far less bulbous, the two outer interdigital mounds are set well apart from the inner pair, and the hypothenar and thenar are widely spaced from each other and the interdigitals.

The single identifiable female in our sample has four pairs of mammae: one pectoral, one postaxillary, and two inguinal.

Skull: Saxatilomys paulinae has an elongate, gracile skull, narrow rostrum, and wide braincase (fig. 6). In dorsal view, the rostrum is moderately long and narrow, its sides gradually tapering towards the anterior end, each side with a large nasolacrimal capsule just in front of the anterior margin of each zygomatic plate. Anterior margin of the nasals is sharply convex, and posteriorly the adjacent premaxillaries project appreciably beyond the nasal-frontal suture. A concave zygomatic notch is evident between rostral wall and the projecting anterior spine of the zygomatic plate. Dorsal portion of each lacrimal bone (in anterolateral pocket of the orbit) is small, rectangular, and fused with the dorsal maxillary zygomatic root (no shared suture with the frontal). Dorsolateral margins of the interorbit, which is about as wide as the rostrum, are defined by wide and high ridges that sweep back along dorsolateral postorbital margins of the frontals and onto the parietals (as temporal ridges) where they diminish in prominence only near the exoccipitalparietal suture. The two postorbital ridges are nearly straight, forming two sides of a triangle (with the apex between the interorbit and the triangular base across the posterolateral points of the frontals). The interparietal is long (in anterior-posterior plane) and mod- 

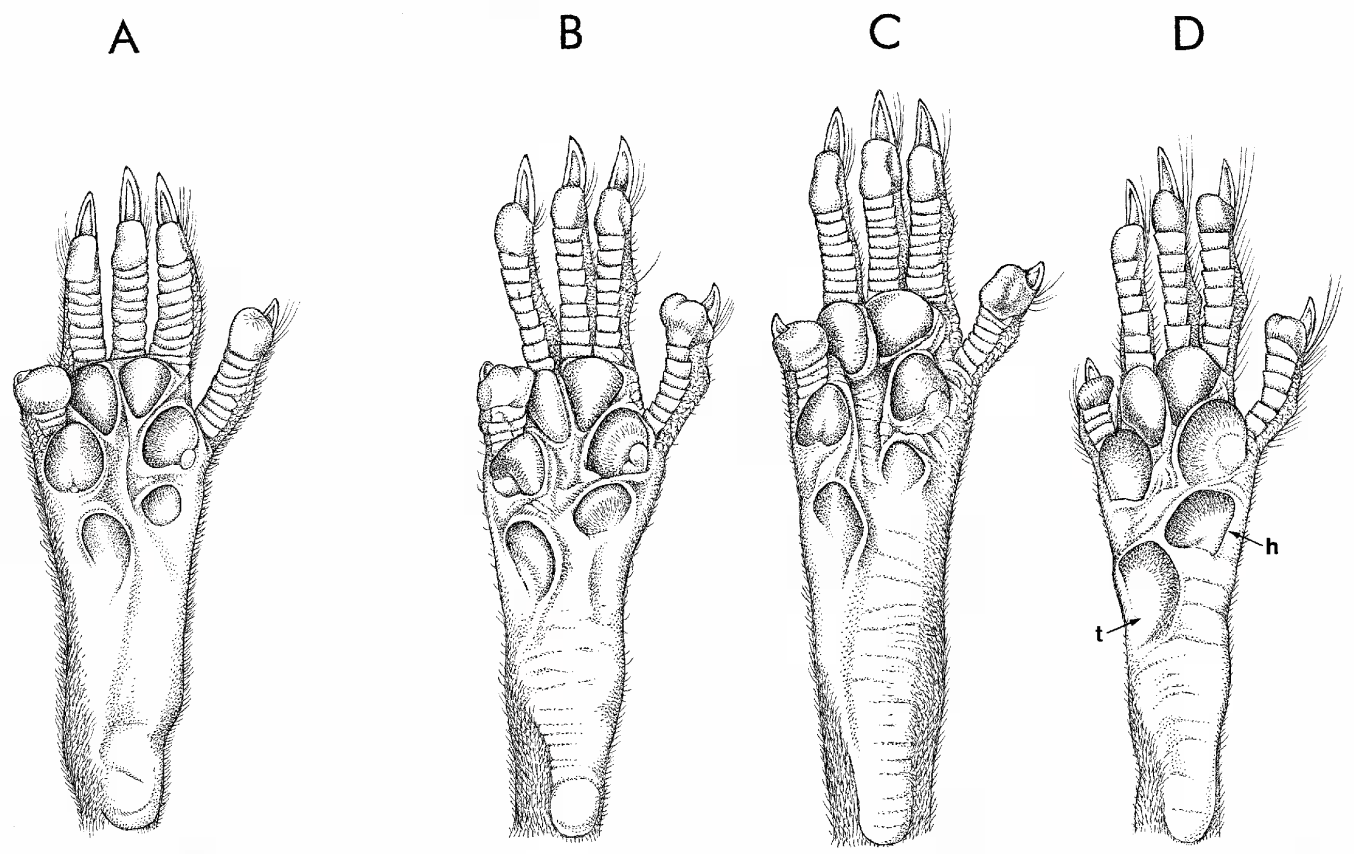

Fig. 5. Plantar views of left hind feet of adults. A, Chiromyscus chiropus (AMNH 268333, southern Vietnam). B, Niviventer langbianis (AMNH 272251, northern Vietnam). C, N. fulvescens (AMNH 272376, northern Vietnam). D, Saxatilomys paulinae (BMNH 2000.292). The feet of the arboreal $C$. chiropus and $N$. langbianis are short and adorned with large and bulbous plantar pads compared with the longer foot and relatively smaller pads in the terrestrial/scansorial $N$. fulvescens. The four interdigital pads (at the bases of the digits), thenar (t), and hypothenar (h) of $S$. paulinae are set appreciably closer than in any of the other species, are more swollen, and larger, not only absolutely but relative to plantar surface.

erately wide (its lateral margins within the parietal-supraoccipital suture, not extending to the parietal-squamosal suture) and its posterior two-thirds roofs a deep occiput with a slightly convex or chevron-shaped posterior margin. Thin zygomatic arches converge slightly towards the anterior portion of the skull; neither zygoma bows out far from the skull.

The skull appears long, low, and with noticeable basicranial flexion when viewed from lateral perspective (figs. 6, 8). The rostrum is somewhat rectangular in side view, and extends slightly beyond the incisor faces to enclose the nasal aperture in a short tube, in which nasals provide the roof and premaxillaries the sides. Most of the broad ventral maxillary root of the zygomatic arch is located anterior to the molar row, so the posterior margin of the zygomatic plate is ap- proximately even with the anterior root of the first molar. The zygomatic plate is very wide relative to the length of the skull; its convex anterior margin projects beyond the dorsal maxillary zygomatic root to form a moderately deep zygomatic notch (best seen in dorsal view). This anterior spine of the plate does not project far enough forward to conceal the nasolacrimal capsule. Maxillary and squamosal zygomatic processes are joined by a moderately long jugal to form a gracile zygomatic arch. The squamosal root of each arch is situated high on the side of the cranium and oriented diagonally so that its posterior ridgelike portion extends diagonally to merge with the squamosal-parietal suture (which forms the temporal ridge) well anterior to the vertical ridge created by the squamosal-exoccipital suture (figs. 6, 8). The parietal does not extend beyond the temporal 

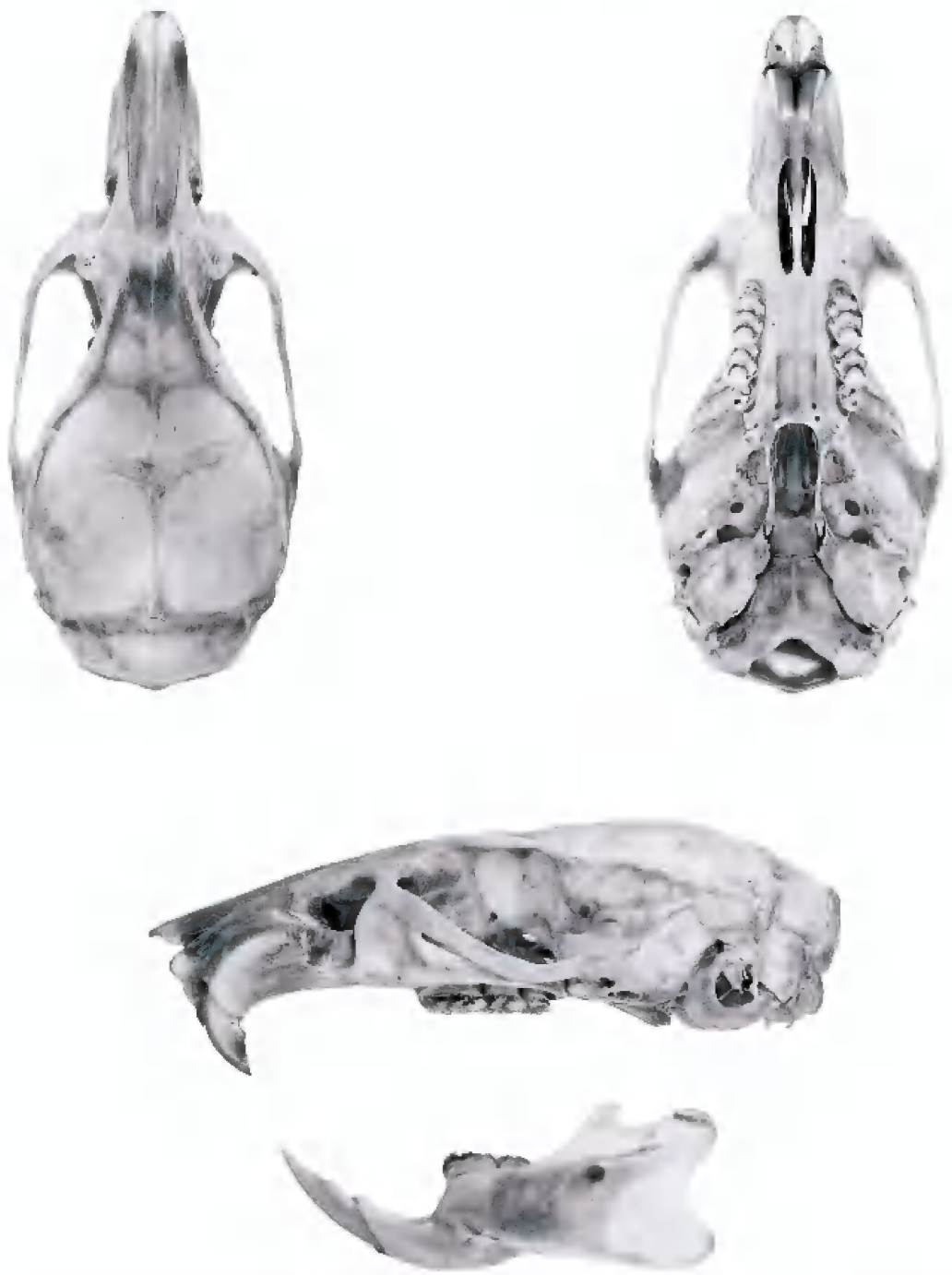

Fig. 6. Views $(\times 2)$ of the cranium and dentary of Saxatilomys paulinae (holotype, BMNH 2000.292) from Lao PDR. Contrast these views with those of Niviventer tenaster (fig. 7), one of the larger species in the genus that is similar to $S$. paulinae in some cranial dimensions (table 4). Note the triangular postorbital region in $S$. paulinae (vase-shaped in $N$. tenaster), the narrower incisive foramina, the longer palate projecting beyond molar rows to form a platform, the diverging molar rows, the wider zygomatic plate, and the pattern formed by the squamosal root of the zygomatic arch relative to the temporal ridge (also see fig. 8).

ridge to project ventrad and contribute to the dorsolateral side of the braincase, which is the configuration in some other Indochinese Asian murines (species of Leopoldamys, for example; see Musser, 1981: 264). Dorsal to the ectotympanic bulla and posterior to the squamosal zygomatic root, the squamosal forming side of the cranium is intact except for a minute subsquamosal foramen at the prominent ridge marking the the squamosalexoccipital suture. This tiny opening is the only landmark identifying where the squa- 

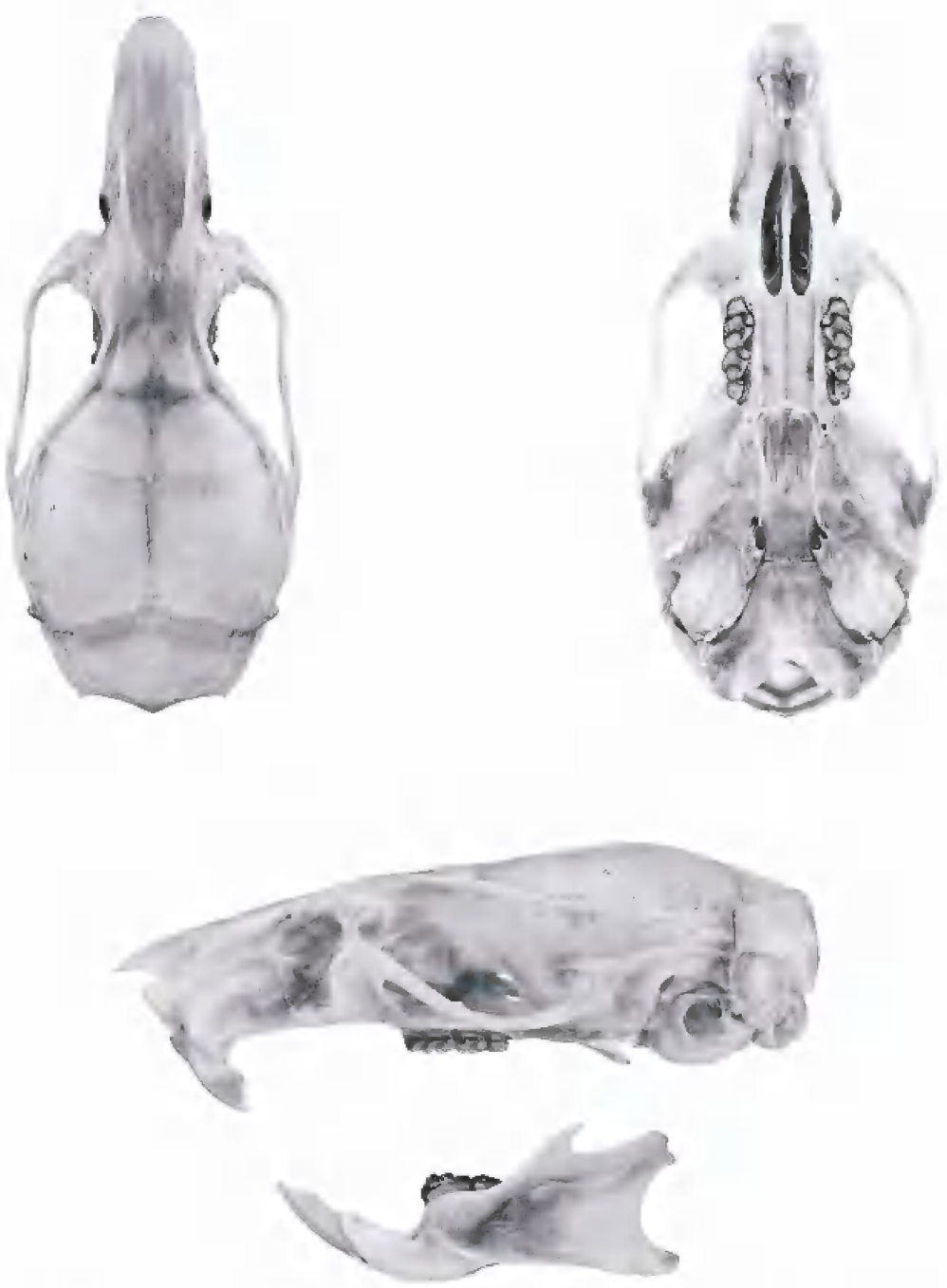

Fig. 7. Views $(\times 2)$ of the adult cranium and dentary of Niviventer tenaster (AMNH 272491) from northern Vietnam. See figure 6 for contrasts with the holotype of Saxatilomys paulinae.

mosal and a wide hamular process of the squamosal have completely fused to form the solid cranial wall. A narrow postglenoid foramen lies between edge of the squamosal and anterodorsal surface of the ectotympanic bulla. That bullar capsule is attached to the squamosal dorsally by the posteroventral portion of that bone, which represents the cranial wall fused with a wide hamular process. An anterior outgrowth of the periotic, the tegmen tympani, is present and overlaps the squamosal, forming an anterior attachment of ectotympanic capsule with the squamosal; there is no posterior suspensory process of the squamosal to which the tegmen tympani attaches (in some sigmodontine rodents, the tegmen tympani overlaps a posterior projection of the squamosal to form one of the suspensory attachments between ectotympanic capsule and squamosal; see the diagrams in Voss, 1993: 19). The moderately inflated mastoid is tightly sutured to squa- 
mosal and exoccipital. It is completely ossified, without the prominent fenestrae found in some murines (Crunomys celebensis, for example; Musser, 1982: 38) and sigmodontines (see Carleton and Musser, 1989: 34); only a very small opening penetrates the dorsal mastoid-exoccipital suture. The deep occiput projects slightly beyond posterior surfaces of the occipital condyles. The ethmoid foramen within the orbit is tiny and the optic foramen moderately large. The dorsal palatine foramen is separate from the sphenopalatine foramen, a configuration usual among Asian murines, with a few exceptions where the two foramina have coalesced (Musser, 1982: 22). One specimen has a slender but substantial bony alisphenoid strut on each side of the skull, posterior to the orbit and dorsad to the pterygoid ridge (the lateral edge of the pterygoid plate). This strut separates the foramen ovale accessorius from the combined buccinator-masticatory foramen on the side of the cranium, and obscures the anterior opening of the alisphenoid canal. The other individual has a strut on the left side, but not on the right. On the strutless side of that skull, the opening to the alisphenoid canal is evident, the foramen ovale accessorius and buccinator-masticatory foramina coalesce (basically disappear), and the course of the buccinator and masticatory nerves is evident, marked by a shallow groove extending from the foramen ovale onto the side of the alisphenoid.

The short rostral tube anterior to faces of the incisors, narrow rostrum, long and narrow incisive foramina, long bony palate, diverging molar rows, wide mesopterygoid fossa and pterygoid plates, and small bullae are the topographic highlights when the ventral surface of the skull is studied (fig. 6). Just behind the incisors is a tiny interpremaxillary foramen, and beyond it the rostrum is perforated by long and narrow (slitlike) incisive foramen, their posterior rims situated slightly before $(0.5 \mathrm{~mm})$ anterior margins of the first molars in one specimen, or projecting $0.5 \mathrm{~mm}$ between them in the other. The bony palate is wide and long, extending 0.6 $\mathrm{mm}$ in one individual and $1.2 \mathrm{~mm}$ in the other beyond the molar rows to form a platform with a slightly concave, smooth, posterior margin unmarked by any bony ridge (7\% and
$15 \%$, respectively, of the palate extends past the third molars). Each posterolateral margin of this shelf merges smoothly with the anterior margin of each pterygoid plate. Except for a pair of oblong posterior palatine foramina (in the maxillary-palatine suture opposite the middle or posterior half of each second molar), a pair of shallow grooves, and small or minute nutrient foramina scattered over the palatal shelf, the ventral surface of the bony palate is smooth. The mesopterygoid fossa is wide, and the dorsolateral margins of its roof are perforated by long and moderately wide sphenopalatine vacuities. On each side of the pterygoid fossa, a robust hamular process of the pterygoid marks the boundary between the mesopterygoid fossa and each adjacent pterygoid plate $(=$ lateral pterygoid plate, parapterygoid plate), its ventral surface sculptured by a shallow pterygoid fossa. In its posterior half, the bony pterygoid plate is breached by the large ventral opening of the foramen ovale, the anterior half is pierced by a small sphenopterygoid vacuity. A shallow trough (in which the infraorbital artery passes) scores the ventral margin of the pterygoid plate between ventral opening of the foramen ovale and the middle lacerate foramen.

Small relative to overall size of the skull, the globular ectotympanic bulla covers all but a narrow wedge of the periotic, and its anteromedial margin meets the basioccipital, so that it is the ectotympanic that forms the posterodorsal wall of all or most of the carotid canal. This structural relationship between ectotympanic and periotic is a derived feature, and is particularly well illustrated in Carleton and Musser (1989: 33) for the sigmodontine Oryzomys palustris. Species of Rattus and its allies have a comparable pattern (Musser and Heaney, 1992: 99). In Asian murines with a less specialized configuration, species of Niviventer and Chiromyscus, for example, a wide, wedge-shaped segment of the periotic is exposed between the dorsal capsular margin and basioccipital, and this wedge of periotic extends anteriorly to form the posterodorsal wall of the carotid canal. The conformation closely resembles that for the sigmodontine, Oligoryzomys (illustrated in Carleton and Musser, 1989: 33), and for some of the Philippine Old Endemics (Musser and Heaney, 1992: 99). Tapering 

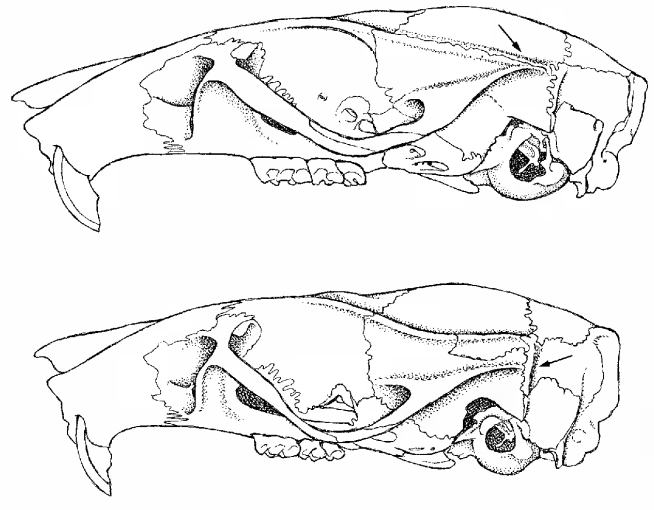

Fig. 8. Diagrammatic views contrasting adult skulls of Saxatilomys paulinae (Top, BMNH 2000.292, holotype) and Niviventer fulvescens (Bottom, AMNH 272365) from northern Vietnam. Arrows indicate the different patterns formed by orientation of the squamosal root of the zygomatic arch. In $S$. paulinae, the ridge extending from the squamosal root meets the temporal ridge (formed along the squamosal-parietal suture) well anterior to the vertical ridge formed by the squamosal-exoccipital suture. In $N$. fulvescens and all other species of Niviventer, as well as Chiromyscus, the posterior extension of the squamosal zygomatic root parallels the temporal ridge to merge with the vertical ridge formed along the squamosal-exoccipital suture. Note also the much wider zygomatic plate of $S$. paulinae, another feature distinguishing that species from most other species of Niviventer. Scale line equals $10 \mathrm{~mm}$.

rostrally from the ectotympanic capsule is a moderately wide and long bony eustachian tube. Between the dorsolateral margin of the tube, the adjacent edge of the basioccipital, and the anterior curve of the ectotympanic is the opening into the carotid canal through which the internal carotid artery passes into the cranium. A spacious middle lacerate foramen separates the anterior slope of the bullar capsule from posterior margin of the pterygoid plate.

The cephalic arterial pattern possessed by Saxatilomys paulinae is not unique among members of Murinae (as that subfamily is delineated by Carleton and Musser, 1984; Musser and Carleton, 2005). Saxatilomys paulinae lacks a sphenofrontal foramen and related squamosoalisphenoid groove, the petro- tympanic fissure between bullar capsule and periotic (= pteriotic, petrosal) is perforated by a spacious stapedial foramen continuous laterally with a deep groove on dorsal surface of the periotic, and there is a shallow but wide groove on the posterior ventral surface of the pterygoid plate. This set of osteological landmarks signals a cephalic arterial pattern in which the supraorbital branch of the stapedial artery is absent and the orbital circulation derives from the distal portion of the infraorbital branch. The infraorbital is a continuation of the stapedial artery, which passes over the dorsal groove in the periotic, through the middle lacerate foramen, continues in the shallow groove ventral to the posterior margin of the pterygoid plate to course through the alisphenoid canal and emerge onto the orbital floor through the anterior alar fissure. Common to most murines (Carleton and Musser, 1984; Musser and Newcomb, 1983; Musser and Heaney, 1992; Musser et al., 1998), this pattern of vessels and associated osteological landmarks is also characteristic of some sigmodontine rodents (described and diagramed for Oligoryzomys by Carleton and Musser, 1989; pattern 2 in Voss, 1988), and is derived compared with the cephalic arterial pattern hypothesized to be primitive for muroid rodents (Bugge, 1985; Carleton, 1980).

The dentary supports a small coronoid process, relative to the extent of the deep ascending ramus, a concave sigmoid notch between coronoid and prominent condyloid processes, and a deeply concave posterior margin connecting condyloid and angular processes (fig. 6). In contrast with the conspicuous ventral masseteric ridge, the dorsal ridge is either undetectable or indicated by a shallow, elongate depression. Besides the ventral masseteric ridge, the only other significant structure that marks an otherwise smooth lateral dentary surface is a slight bulge below the anterior root of the coronoid process that marks termination of the incisor alveolus within the bone. In no specimen did the incisor capsule extend so far caudad as to project into the condyloid process (checked by shining a high-intensity light through the dentary), as it does in some other murines (Musser and Heaney, 1992: 84). Topography of the lingual dentary surface re- 
sembles that characteristic of most other murines, the primary landmarks being a prominent lingual ridge above which is the large mandibular foramen (as in Papagomys armandvillei, for example; see Musser et al., 1986: 5). The body of the dentary projects anteriorly beyond the molar row as a moderately short and stocky tube containing the incisor. Just in front of the molar row on the dorsolateral labial surface is a small mental foramen.

Enamel faces of upper and lower molars are smooth, without grooves; uppers are dark orange, lowers are pale orange. Thickness of the enamel relative to the dentine is similar to that in species of Rattus and many other murines (Musser and Heaney, 1992: 79). The uppers curve caudad after emerging from the rostrum (opisthodont conformation, fig. 6; see Thomas, 1919; Hershkovitz, 1962: 103). Enamel surfaces of the uppers are at right angles to the long axis of the skull so their combined tips form a straight cutting edge (as in species of Rattus; see Musser and Heaney, 1992: 79), not curved or V-shaped (as in some Philippine and Sulawesi endemics; see Musser and Heaney, 1992; Musser and Durden, 2002). The lowers are moderately long and curved, their cutting tips slightly curved.

Alveolar patterns for roots of upper molars match those in most species of Niviventer (table 5). The first molar is anchored by five roots: a large anterior, two robust lingual roots, a large posterior holdfast, and a small labial root. The pattern is derived for murines (an anterior root, a lingual, and a posterior holdfast comprise the primitive configuration). Four roots hold the second molar in place and three are beneath the third molar. Two roots, a large anterior and a posterior, anchor each lower molar, which is the primitive pattern for murines (Musser and Newcomb, 1983; Musser and Heaney, 1992).

Maxillary molar rows are long relative to length of skull (18\% of occipitonasal length, and strongly diverge posteriorly (width of bony palate is considerably greater between third molars than between the first molars (fig. 6). Occlusal surfaces of the brachydont (low-crowned) molars are simple in topography (fig. 10). The first upper molar consists of two anterior rows of cusps, each in the form of a broad chevron, and a large, somewhat diamond-shaped posterior surface. The anteriormost chevron is comprised of cusps $\mathrm{t} 1$, $\mathrm{t} 2$, and $\mathrm{t} 3$ so coalesced that their limits are obliterated, at least in adults. Coalesced cusps $\mathrm{t} 4, \mathrm{t} 5$, and $\mathrm{t} 6$ form the second chevron, although the labial and lingual cusps retain some definition. The large, chunky posterior third of the molar consists primarily of cusp t8 merged with a smaller, ridgelike cusp $\mathrm{t} 9$ to form the distorted diamond-shaped chewing surface. On the occlusal surface of each second upper molar, the anterocone is represented by a large cusp $\mathrm{t} 1$ forming the anterolingual portion of the tooth. In both specimens, a small cusp $\mathrm{t} 3$ sits on the anterolabial margin. The complete chevron and chunky posterior portion of the tooth, in size and shape, closely resembles comparable rows in the first molar. Each third molar has an occlusal pattern that is basically a compacted form of that characterizing the second molar: a conspicuous cusp $\mathrm{t} 1$, but no cusp $\mathrm{t} 3$, an arcuate lamina formed from cusps $t 4, t 5$, and t6, and small posterior oblong chunk (presumably cusp t8). We could not detect a cusp t7 (on the lingual cingulum between cusps $\mathrm{t} 4$ and $\mathrm{t} 8$ when present; see Musser and Newcomb, 1983: 333), posterior cingulum (pressed against the posterior margin of cusp t8, if present; see Musser and Newcomb, 1983: 333), accessory cusplets on any of the upper molars, or enamel ridges projecting longitudinally from each lamina. When present these structures provide complexity to the occlusal surface and in some murine species actually increase the area for mastication.

Occlusal surfaces of the lower molars also exhibit uncomplicated patterns. An anterolingual cusp coalesced with a smaller anterolabial forms the anteroconid, the anteriormost cusp row, which is narrower than the two laminae behind it. The second and third are in the shape of narrow chevrons and represent unions of protoconid-metaconid and hypoconid-entoconid, respectively. A roughly triangular or oblong posterior cingulum forms the posterior fourth of the molar. Except for lacking a complete anteroconid, occlusal cusp patterns of the second molar resemble patterns seen in the first. The anterior half of each third molar consists of a front 

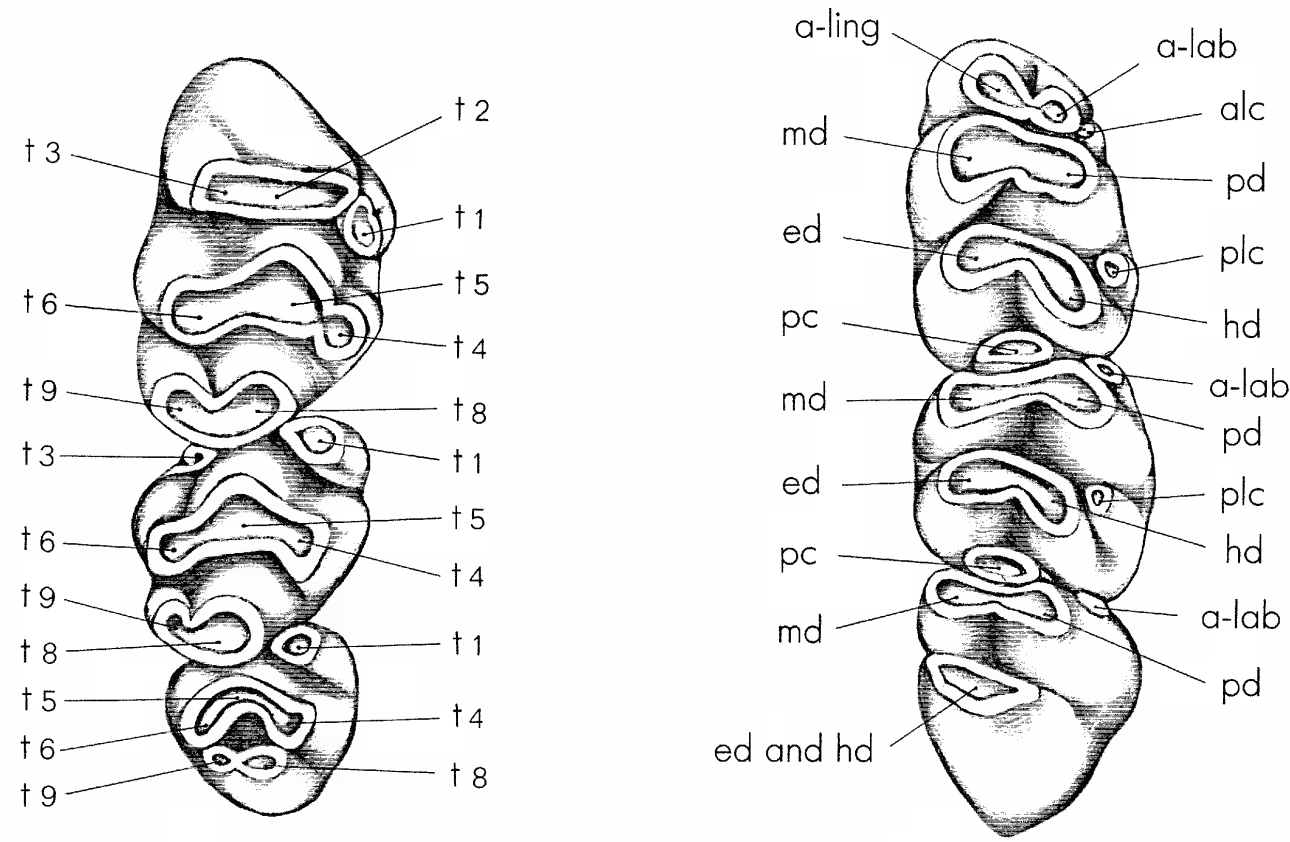

Fig. 9. Occlusal views of right maxillary molar row (left) and right mandibular molar row (right) from Bunomys chrysocomus illustrating structural terms. Maxillary molar cusps are numbered according to Miller's (1912) scheme and referred to in the text with the prefix " $t$ ". Abbreviations for mandibular molars: a-lab, anterolabial cusp; a-ling, anterolingual cusp; alc, anterior labial cusplet; ed, entoconid; hd, hypoconid; md, metaconid; pc, posterior cingulum; pd, protoconid; plc, posterior labial cusplet. Terminology for mandibular molars derives, with slight modifications, from Weerd (1976: 44).

chevron formed by union of protoconid and metaconid and behind that a large oblong structure likely representing the complete fusion of hypoconid and entoconid. The anteroconid is represented by an anterior labial cusp, which is a prominent part of the coronal pattern on each second molar in both specimens, but forms a smaller contribution on each third molar in the two rats. We had difficulty determining the frequency of posterior labial cusplets. This small cone is clearly absent from the third molar in both specimens. Judged by the anterolabial outline of the posterior lamina on first and second molars in each specimen, there were never any attached posterolabial cusplets, but other laminar outlines reflect the coalescence of a cusplet with the anterolabial laminar margin.

\section{DISCUSSION}

Comparisons with Extant Species: Saxatilomys paulinae is a member of the Dac- nomys Division of Musser and Carleton (2005), which contains the Philippine Anonymomys (one species); Indo-malayan Chiromyscus (one), Dacnomys (one), Leopoldamys (six), and Niviventer (17); and Sri Lankan Srilankamys (one). Geographic distributions, taxonomy, descriptions of morphologies and other traits, and postulated phylogenetic relationships are provided by Musser (1981), Musser and Newcomb (1983), Musser and Heaney (1992), and Musser and Carleton (2005). In body conformation, limb and tail proportions, and general morphology of skull and dentition, $S$. paulinae most closely resembles species of Niviventer and Chiromyscus: our comparisons contrast samples of those genera with our two examples of Saxatilomys.

As prelude to our comparisons, we explain that the present contents of Chiromyscus (one species) and Niviventer (17 species; taxonomy and geographic distributions for both 

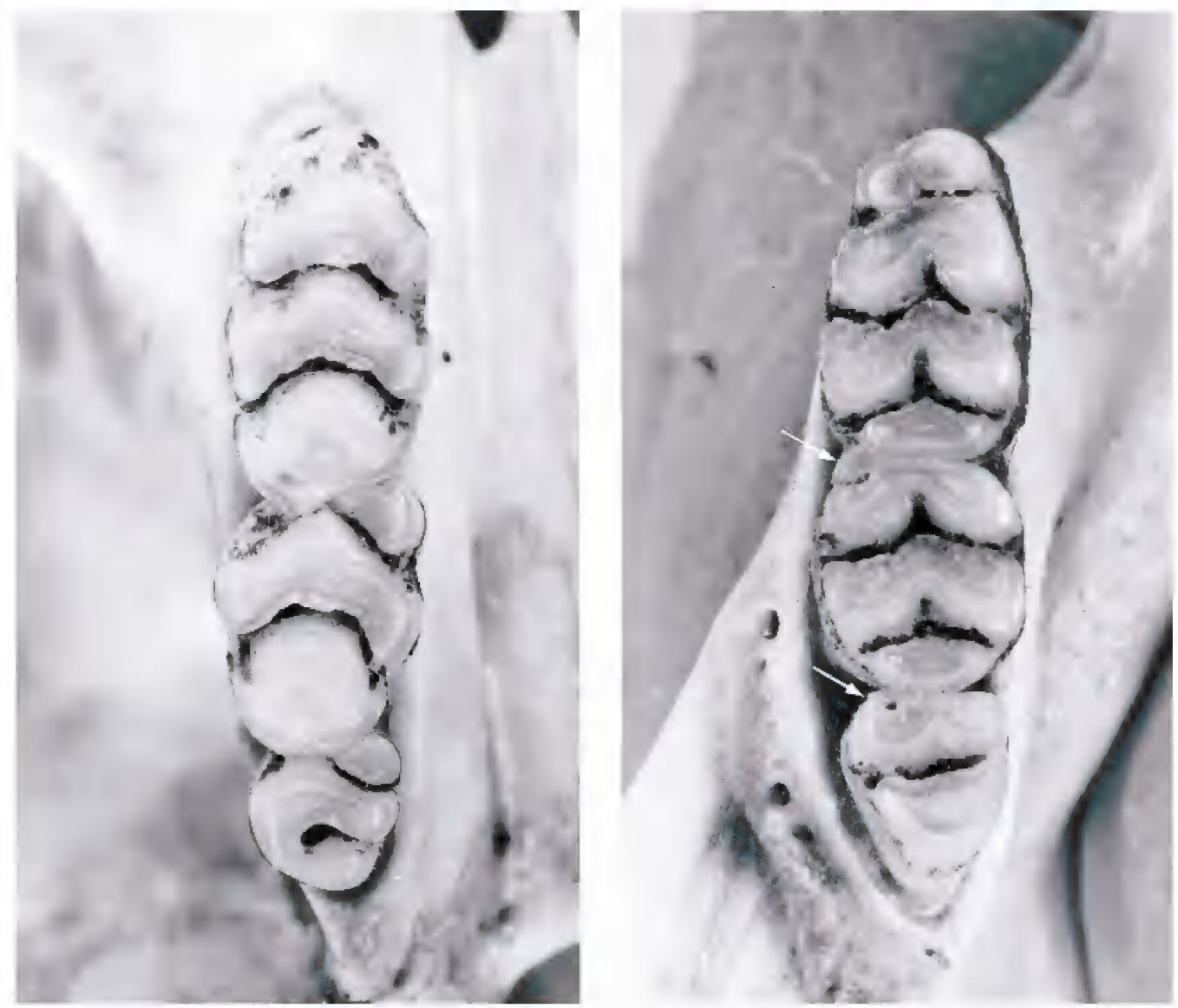

Fig. 10. Occlusal views of right maxillary molar row (left) and left mandibular molar row (right) of Saxatilomys paulinae (holotype, BMNH 2000.292; measurements are listed in table 1). See figure 9 for terminology of cusps and cusplets. Remember that the lower molar row in figure 9 is from the right side, but the left side is shown for $S$. paulinae (just reverse labial and lingual labeling). Arrows point to the prominent anterolabial cusps on second and third molars of $S$. paulinae.

genera are summarized in Musser and Carleton, 2005) will likely be altered after careful systematic revision of these genera. Musser (1981) characterized them, provided a provisional diagnosis and contents, but his exposition was more of a summary and meant to be a working hypothesis, not a systematic revision. That kind of study has yet to be realized. Most species will remain in Niviventer but two sets may eventually be differently allocated. Except for its nail-like claw on the hallux, shelf-like ridges bordering dorsolateral margins of the postorbital region and braincase, roots beneath the first up- per molar (table 5), color pattern of the dorsal pelage, large and very bulbous plantar pads set close together, other external and most cranial and dental characteristics of the arboreal $C$. chiropus are similar to the species of Niviventer, particularly $N$. langbianis (Musser, 1981; Musser and Lunde, ms). The latter is also arboreal (observations derived from trapping surveys in Vietnam by Lunde and Musser), and shares with $C$. chiropus comparable prominent postorbital and temporal ridges, the number of roots anchoring the first upper molar (table 5), a nail-like claw on the hallux, a color pattern that does 
not match in details but is generally similar, and equal expression of plantar pads. A revisionary inquiry may either move $N$. langbianis to Chiromyscus, or $C$. chiropus will be subsumed within Niviventer (that name would then be a synonym of the older Chiromyscus).

Niviventer andersoni and $N$. excelsior are another set now in Niviventer that will probably be removed. Musser (1981) described a suite of cranial and dental traits that contrast with the summation of characters common to the other species in Niviventer. Should information from other anatomical systems, and that derived from karyological and biochemical surveys, support the cranial and dental distinctions, he (p. 328) noted "... that the phylogenetic relationship between Niviventer and the $N$. andersoni division [would be] better expressed by excluding the latter from $\mathrm{Ni}$ viventer and placing $N$. andersoni and $N$. excelsior in a genus of their own."

We accept the current, although provisional, contents of Niviventer for our comparative context in this report. We generally will also refer only to "Niviventer", understanding that the contrasts between species in that genus and Saxatilomys are much the same as between the latter and $C$. chiropus. The specimens we used for side-by-side comparisons with our sample of Saxatilomys are listed in the appendix. These also form the substance of a systematic revision of Indochinese species in Niviventer that will be published later (Musser and Lunde, ms.).

External traits: Body size, build, limb and tail proportions, and number of teats of Saxatilomys paulinae resemble most species of Niviventer of similar body size-S. paulinae simply looks like a Niviventer and not like any other species in any other genus. The proportional relationship between lengths of tail and body in Saxatilomys, for example, fall well within the range of variation found among species of Niviventer. The tail is equal to or slightly longer than head and body length in $N$. hinpoon (Marshall, 1988), but in all other species it is much longer, just as it is in Saxatilomys (table 1; see descriptions and measurements in Musser, 1970, 1973, 1981; Musser and Chiu, 1979; Lunde and Son, 2001). Number of teats of the Lao species matches that common to most species of Niviventer. Saxatilomys paulinae has four pairs of teats (one pectoral, one postaxillary, and two inguinal); of all the species of Niviventer, only N. brahma and $N$. eha have a different count, three pairs instead of four-no pectoral pair (Musser, 1981).

The dark gray fur covering both upperparts and underparts of Saxatilomys, as well as size of the plantar pads, are the traits forming striking contrasts with any described species of Niviventer. In all species of that genus, upperparts range from buffy or brownish gray, through brown, to reddish brown (Musser, 1981). Niviventer brahma and $N$. eha have grayish white underparts (hairs are gray in basal half, silvery in distal half; Musser, 1970), $N$. hinpoon has a buffy pale gray venter (hairs pale gray basally, buffy in distal half; Marshall, 1988), but all the other species have white venters. The dark gray fur covering upperparts and underparts in Saxatilomys is not matched by that fur coloration and counter-shading pattern in any example of any species of Niviventer. The plantar pads of Saxatilomys are larger, more bulbous, and set closer, relative to plantar surface, than in any terrestrial or scansorial species of Niviventer, including $N$. hinpoon, which is regarded as being closely associated with limestone cliff habitats (Marshall, 1988), or even the arboreal $N$. langbianis and Chiromyscus chiropus (fig. 5); N. fulvescens exhibits the general Niviventer configuration of size and distribution of plantar pads (fig. 5).

Skull: The skull of Saxatilomys paulinae is similar in size (as indexed by occipitonasal length) to that of $N$. tenaster, one of the largest of the Indochinese species of Niviventer (compare figures 6 and 7; table 4; also compare the cranial illustrations of species of $\mathrm{Ni}$ viventer in Musser, 1981: 248-254, with figure 6 in which the skull of $S$. paulinae is illustrated; the contrasts seen between $S$. paulinae and $N$. tenaster extend to all the other species of Niviventer, as well as Chiromyscus). Other resemblances are apparent in the illustrations, but there are also significant differences. Compared with Niviventer, as exemplified by $N$. tenaster, Saxatilomys has: (1) high ridges bordering the postorbital region that sweep back in the shape of a triangle (apex is in center of the interorbit, and the base lies across the back of the frontals); 
TABLE 4

\section{Summary Statistics for Cranial and Dental Measurements (mm) from Samples of Saxatilomys paulinae and the Three Species of Niviventer Occurring in \\ Laos and Vietnama}

(Mean, plus or minus one SD, observed range in parentheses, and number of specimens in each sample are listed for each measurement. Sample contains both sexes, and a range in age from young to old adults. Individuals measured are identified in the footnote.)

\begin{tabular}{|c|c|c|c|c|}
\hline & $\begin{array}{l}\text { S. paulinae } \\
\text { (Lao PDR) }\end{array}$ & $\begin{array}{l}\text { N. tenaster } \\
\text { (Vietnam) }\end{array}$ & $\begin{array}{l}\text { N. fulvescens }{ }^{\mathrm{d}} \\
\text { (Vietnam) }\end{array}$ & $\begin{array}{l}\text { N. langbianis } \\
\text { (Vietnam) }\end{array}$ \\
\hline ONL & $\begin{array}{l}40.4 \pm 0.14 \\
(40.3-40.5) 2\end{array}$ & $\begin{array}{l}39.9 \pm 1.38 \\
(37.0-41.9) 11\end{array}$ & $\begin{array}{l}36.9 \pm 1.56 \\
(33.6-40.0) 28\end{array}$ & $\begin{array}{l}36.0 \pm 1.37 \\
(33.3-40.5) 48\end{array}$ \\
\hline ZB & $\begin{array}{l}18.1 \pm 0.57 \\
(17.7-18.5) 2\end{array}$ & $\begin{array}{l}17.2 \pm 0.48 \\
(16.5-18.0) 11\end{array}$ & $\begin{array}{l}16.3 \pm 0.68 \\
(15.0-17.7) 28\end{array}$ & $\begin{array}{l}16.9 \pm 0.62 \\
(15.7-18.9) 48\end{array}$ \\
\hline IB & $\begin{array}{l}5.9 \pm 0.14 \\
(5.8-6.0) 2\end{array}$ & $\begin{array}{r}6.1 \pm 0.26 \\
(5.8-6.7) 11\end{array}$ & $\begin{array}{c}5.7 \pm 0.29 \\
(5.0-6.3) 28\end{array}$ & $\begin{array}{r}5.8 \pm 0.29 \\
(5.1-6.5) 48\end{array}$ \\
\hline LR & $\begin{array}{l}13.5 \pm 0.00 \\
2\end{array}$ & $\begin{array}{l}13.1 \pm 0.75 \\
(11.8-14.5) 11\end{array}$ & $\begin{array}{l}11.8 \pm 0.71 \\
(10.5-13.5) 28\end{array}$ & $\begin{array}{l}11.0 \pm 0.65 \\
(9.7-12.7) 48\end{array}$ \\
\hline $\mathrm{BR}$ & $\begin{array}{l}6.0 \pm 0.07 \\
(5.9-6.0) 2\end{array}$ & $\begin{array}{r}6.6 \pm 0.25 \\
(6.4-7.3) 11\end{array}$ & $\begin{array}{r}6.1 \pm 0.35 \\
(5.3-6.7) 28\end{array}$ & $\begin{array}{r}5.9 \pm 0.31 \\
(5.3-6.7) 48\end{array}$ \\
\hline $\mathrm{BBC}$ & $\begin{array}{l}16.3 \pm 0.63 \\
(15.8-16.7) 2\end{array}$ & $\begin{array}{l}15.5 \pm 0.23 \\
(15.2-16.1) 11\end{array}$ & $\begin{array}{l}14.9 \pm 0.53 \\
(13.7-15.7) 28\end{array}$ & $\begin{array}{l}15.0 \pm 0.36 \\
(14.3-16.2) 48\end{array}$ \\
\hline $\mathrm{HBC}$ & $\begin{array}{l}10.7 \pm 0.50 \\
(10.3-11.0) 2\end{array}$ & $\begin{array}{l}10.6 \pm 0.27 \\
(10.2-11.0) 11\end{array}$ & $\begin{array}{l}10.0 \pm 0.30 \\
(9.4-10.5) 28\end{array}$ & $\begin{array}{c}9.9 \pm 0.36 \\
(9.0-10.9) 48\end{array}$ \\
\hline BZP & $\begin{array}{l}4.1 \pm 0.07 \\
(4.0-4.1) 2\end{array}$ & $\begin{array}{r}3.4 \pm 0.21 \\
(3.1-3.7) 11\end{array}$ & $\begin{array}{r}3.2 \pm 0.24 \\
(2.8-3.7) 28\end{array}$ & $\begin{array}{r}3.4 \pm 0.26 \\
(2.9-4.0) 48\end{array}$ \\
\hline LD & $\begin{array}{l}10.2 \pm 0.42 \\
(9.9-10.5) 2\end{array}$ & $\begin{array}{l}10.2 \pm 0.50 \\
(9.2-10.9) 11\end{array}$ & $\begin{array}{c}9.3 \pm 0.56 \\
(7.6-10.2) 28\end{array}$ & $\begin{array}{c}9.1 \pm 0.54 \\
(7.9-10.4) 48\end{array}$ \\
\hline LIF & $\begin{array}{l}7.0 \pm 0.35 \\
(6.7-7.2) 2\end{array}$ & $\begin{array}{r}6.7 \pm 0.34 \\
(6.3-7.3) 11\end{array}$ & $\begin{array}{r}6.3 \pm 0.35 \\
(5.5-6.8) 28\end{array}$ & $\begin{array}{r}6.6 \pm 0.45 \\
(5.6-7.5) 48\end{array}$ \\
\hline BIF & $\begin{array}{l}2.3 \pm 0.28 \\
(2.1-2.5) 2\end{array}$ & $\begin{array}{r}3.0 \pm 0.08 \\
(2.8-3.1) 11\end{array}$ & $\begin{array}{r}2.6 \pm 0.21 \\
(2.2-3.0) 28\end{array}$ & $\begin{array}{r}2.6 \pm 0.19 \\
(2.2-3.1) 48\end{array}$ \\
\hline LBP & $\begin{array}{l}8.6 \pm 0.21 \\
(8.4-8.7) 2\end{array}$ & $\begin{array}{r}7.0 \pm 0.22 \\
(6.5-7.3) 11\end{array}$ & $\begin{array}{r}6.6 \pm 0.30 \\
(5.9-7.1) 28\end{array}$ & $\begin{array}{r}6.1 \pm 0.36 \\
(5.3-6.9) 48\end{array}$ \\
\hline BBP & $\begin{array}{l}3.6 \pm 0.28 \\
(3.2-3.6) 2\end{array}$ & $\begin{array}{r}3.9 \pm 0.21 \\
(3.6-4.3) 11\end{array}$ & $\begin{array}{r}3.6 \pm 0.20 \\
(3.1-3.9) 28\end{array}$ & $\begin{array}{r}3.3 \pm 0.19 \\
(3.0-3.9) 48\end{array}$ \\
\hline PPL & $\begin{array}{l}12.5 \pm 0.42 \\
(12.2-12.8) 2\end{array}$ & $\begin{array}{l}13.9 \pm 0.58 \\
(12.5-14.6) 11\end{array}$ & $\begin{array}{l}12.5 \pm 0.85 \\
(10.7-14.5) 28\end{array}$ & $\begin{array}{l}12.3 \pm 0.68 \\
(10.9-14.5) 48\end{array}$ \\
\hline BMF & $\begin{array}{l}2.8 \pm 0.07 \\
(2.7-2.8) 2\end{array}$ & $\begin{array}{r}3.3 \pm 0.35 \\
(2.4-3.7) 11\end{array}$ & $\begin{array}{r}2.8 \pm 0.24 \\
(2.4-3.5) 28\end{array}$ & $\begin{array}{r}2.7 \pm 0.24 \\
(2.3-3.4) 48\end{array}$ \\
\hline LB & $\begin{array}{l}5.4 \pm 0.21 \\
(5.2-5.5) 2\end{array}$ & $\begin{array}{r}5.4 \pm 0.16 \\
(5.2-5.7) 11\end{array}$ & $\begin{array}{c}4.6 \pm 0.10 \\
(4.4-4.8) 28\end{array}$ & $\begin{array}{r}5.4 \pm 0.18 \\
(5.5-5.8) 48\end{array}$ \\
\hline CLM1-3 & $\begin{array}{l}7.3 \pm 0.06 \\
(7.2-7.3) 3\end{array}$ & $\begin{array}{r}6.1 \pm 0.15 \\
(5.9-6.4) 11\end{array}$ & $\begin{array}{r}6.1 \pm 0.15 \\
(5.8-6.3) 28\end{array}$ & $\begin{array}{r}6.2 \pm 0.17 \\
(5.8-6.5) 48\end{array}$ \\
\hline BM1 & $\begin{array}{l}2.1 \pm 0.07 \\
(2.0-2.1) 2\end{array}$ & $\begin{array}{r}1.8 \pm 0.07 \\
(1.7-1.9) 11\end{array}$ & $\begin{array}{r}1.8 \pm 0.06 \\
(1.6-1.9) 28\end{array}$ & $\begin{array}{r}1.8 \pm 0.08 \\
(1.7-2.0) 48\end{array}$ \\
\hline
\end{tabular}

a Niviventer tenaster, $N$. fulvescens, and $N$. langbianis have not been collected in the Khammouan Limestone region. At that latitude, $N$. tenaster is found only in highlands. We suspect that $N$. fulvescens and $N$. langbianis will eventually be reported from the area. The former is common thoughout Laos and Vietnam, the latter is common in some places but not usually encountered by collectors unless traps are set on arboreal substrates. Chiromyscus chiropus is the only close relative of Niviventer so far recorded from the Khammouan Limestone (Smith et al., 2004).

${ }^{\text {b }}$ Lao PDR: AMNH 272953, BMNH 2000.292 (holotype).

${ }^{c}$ Northern Vietnam, Lao Cai Province: FMNH 39220, 39222-39224, 39226, 39229, 39234, 39331, 39235, $39237,39243$.

d Northern Vietnam, Há Tinh Province: AMNH 272218, 272228, 272258, 272364-272366, 272394, 272396, 272399, 272410, $272464,272537,272551,272562,272252,272254,272257,272287,272393,272406,272414,272416,272428,272436$, $272451,272466,272621,272638$ (italicized numbers designate specimens deposited in the IEBR).

' Northern Vietnam, Há Tinh Province: AMNH 272147, 272156, 272160, 272166, 272178, 272194, 272197, 272202, 272204, 272205-272207, 272208, 272209, 272222, 272236, 272245, 272247, 272248, 272249, 272262, 272263, 272265, 272266, $272267,272269,272289,272437,272457,272460,272468,272480,272481,272540,272432,272459,272461,272527$, 272528, 272530, 272531, 272533, 272536, 272546, 272549, 272553, 272555, 272591, 272637 (italicized numbers designate specimens deposited in the IEBR ). 
the ridges sweep out from the interorbit in a vase-shaped curve in $N$. tenaster and all other species of Niviventer; (2) a broader zygomatic plate; (3) the squamosal root of each zygomatic arch oriented diagonally, so it extends as a diagonal ridge to merge with the temporal ridge (squamosal-parietal suture) at a point well anterior to the vertical ridge formed by the squamosal-exoccipital suture (in all species of Niviventer, the squamosal process of each zygomatic arch is parallel to the temporal ridge, and its posterior ridgelike extension runs parallel to the temporal ridge to merge with the squamosal-exoccipital suture, and not with the squamosal-parietal suture; see the drawing in fig. 8); (4) much narrower, slitlike incisive foramina (broader, more expansive foramina in N. tenaster, a conformation shared by the other species in Niviventer); (5) strongly posteriorly diverging molar rows (parallel or only slightly diverging in all Niviventer); (6) a bony palate that projects appreciably beyond posterior margins of third molars to form a platform (posterior margin of bony palate ends about $0.5 \mathrm{~mm}$ anterior to posterior surfaces of upper third molars, even with them, or no more than about $0.5 \mathrm{~mm}$ beyond in species of Niviventer); (7) a posterior margin of the bony palate that is smooth or only slightly swollen (the palatal border is defined by a prominent and thick bony ridge in $N$. tenaster and other species of Niviventer); and (8) an ectotympanic bulla concealing most of periotic and meeting the basisphenoid anterior to the periotic wedge, so that the slanting posterodorsal wall of the carotid canal is mostly formed by the ectotympanic and not the periotic (in $N$. tenaster and all other species of Niviventer, a wide, wedge-shaped segment of the periotic is exposed between the dorsal ectotympanic capsular margin and basioccipital, and this wedge of the periotic extends anteriorly to form the posterodorsal wall of the carotid canal).

We detected no significant differences, other than size, between Saxatilomys paulinae and $N$. tenaster (and the other species of Niviventer) in overall shape of the dentary; positions of foramina; expanse of coronoid, condyloid, and angular processes relative to body of the dentary; expression of masseteric and lingual ridging; or posterior terminus of the incisor capsule.

Dentition: Shapes of the upper and lower incisors, their enamel color and thickness, and opisthodont conformation of the uppers relative to the rostrum resemble incisors in all species of Niviventer. Occlusal patterns of the upper and lower molars fit within the range of variation we observed among most species of Niviventer (contrast figure 10 with illustrations of molar rows in Musser, 1981: 242-243). The anterior lamina on the first upper molar in $N$. andersoni and $N$. excelsior is nearly straight (closely resembling shape of the comparable lamina in species of Leopoldamys; see illustrations in Musser, 1981: 262-263), and contrasts with the comparable broad chevron-shaped lamina in S. paulinae, but those two species also differ from most other species of Niviventer in this trait.

There are two striking differences between $S$. paulinae and species of Niviventer. First, the Laos rat has much longer molar rows than does any species of Niviventer (selected samples are compared in table 4) except for $N$. andersoni, which has molar rows comparable in length $(\overline{\mathrm{x}}=7.3 \mathrm{~mm}$, range is $6.9-$ $7.5 \mathrm{~mm}$ for 18 specimens of $N$. andersoni; $\overline{\mathrm{x}}$ $=7.3 \mathrm{~mm}$, range is $7.2-7.3 \mathrm{~mm}$ for three examples of $S$. paulinae). Second, $S$. paulinae has prominent anterolabial cusps on second lower molars, and small but distinct anterolabial cusps on third lower molars. Anterolabial cusps occur at very low frequencies in samples of Niviventer. For example, of the 17 samples representing 12 species that Musser (1981: 245) surveyed, 673 individuals exhibited no sign of the cusp on second molars, and it was present in only 52 ( $8 \%$ of the 725 specimens). The frequency was even lower for the anterolabial cusp on the third lower molar: of 624 specimens, only two had anterolabial cusps (less than $1 \%$ ).

In concert with the occlusal patterns on upper and lower molars of $S$. paulinae, which fall within the range of variation observed among the species of Niviventer, the number of roots anchoring each upper molar is similar. Saxatilomys paulinae and all species of Niviventer have multi-rooted upper molars (table 5; also see Chaimanee, 1998, and Zheng, 1993). First upper molars can be 
TABLE 5

Number of Roots on M1 and m1 in Saxatilomys, Chiromyscus, and Selected Species of Niviventer

(Number opposite species indicates specimens examined. Symbol key: 4/4-M1 with large anterior, single lingual, and posterior roots, and a small labial root; $\mathrm{m} 1$ with large anterior and posterior roots, and small labial and lingual roots. 5/4-M1 with large anterior posterior roots, two lingual, and a small labial root; $\mathrm{m} 1$ with large anterior and posterior roots, and small labial and lingual anchors. $5 / 2-\mathrm{M} 1$ with large anterior and posterior roots, two lingual, and a small labial root; $\mathrm{m} 1$ with a large anterior root and large posterior root. Specimens surveyed are in AMNH, BMNH, FMNH, and USNM) ${ }^{\mathrm{a}}$

\begin{tabular}{|c|c|c|c|}
\hline \multirow[b]{2}{*}{ Species } & \multicolumn{3}{|c|}{ Roots (M1/m1) } \\
\hline & $4 / 4$ & $5 / 4$ & $5 / 2$ \\
\hline S. paulinae (Lao PDF) & - & - & 11 \\
\hline N. andersoni (China: Sichuan, Yunnan) & - & 46 & - \\
\hline N. excelsior (China: Sichuan) & - & 12 & - \\
\hline N. brahma (northern Myanmar) & - & 7 & - \\
\hline N. eha (northern Myanmar) & - & 17 & - \\
\hline N. langbianis (Vietnam) & 40 & - & - \\
\hline N. cremoriventer (Sunda Shelf) & - & 53 & - \\
\hline N. hinpoon (Thailand) & - & 15 & 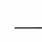 \\
\hline N. confucianus (China, northern Myanmar) & - & 53 & - \\
\hline N. tenaster (China: Hainan, Vietnam) & - & 55 & - \\
\hline N. fulvescehs (Vietnam) & - & 50 & - \\
\hline N. conninga (Taiwan) & - & 53 & - \\
\hline$N$. rapit (northern Borneo) & - & 6 & - \\
\hline N. fraternus (Sumatra) & - & 20 & - \\
\hline N. lepturus (Java) & - & 21 & - \\
\hline N. cameroni (Malay Peninsula) & - & 42 & - \\
\hline C. chiropus (Vietnam) & 2 & - & - \\
\hline
\end{tabular}

${ }^{a}$ Labial roots are divided into two or more rootlets on some upper and lower molars, but we did not count these projections as independent roots. In some specimens, the posterior root on the lower molar is furrowed down the middle, suggesting separate posterolingual and posterolabial anchors, but we scored this configuration as one large root. The sample of $S$. paulinae consists of two whole animals and fragments recovered from owl pellets, so the count is derived from 3 first upper molars and 8 first lower molars. Sample sizes for all the other species are based on complete specimens.

used as examples. Most species of Niviventer have five-rooted first upper molars: a large anterior, two smaller lingual, a large posterior, and a small labial. Some specimens have one or more labial rootlets in addition to the primary labial anchor. Niviventer langbianis and Chiromyscus chiropus are exceptionsthey have only a single lingual root, so four roots anchor each first upper molar. Both Saxatilomys and species of Niviventer have four roots beneath each second upper molar, and three associated with the third upper molar (not included in table 5).

Four roots (large anterior and posterior holdfasts, smaller labial and lingual roots) anchor each first lower molar in all Niviventer and Chiromyscus (table 5). Two to four is the range in number of roots anchoring each second lower molar among species of Niviventer, and each third lower molar has either two or three roots. By contrast, each lower molar of $S$. paulinae has only two roots (an anterior and a posterior), which is the primitive pattern for murines, in contrast to the derived pattern exhibited by species of Niviventer (Musser and Newcomb, 1983; Musser and Heaney, 1992).

Summary: Saxatilomys paulinae resembles species of the Indo-malayan Niviventer in many aspects of its external, cranial, and dental morphology, but other traits exclude it from Niviventer as that genus is currently diagnosed (Musser, 1981). No species of $\mathrm{Ni}$ viventer, whether occurring in Indochina or 
on the islands on the Sunda Shelf, has Saxatilomys's dark gray upperparts and frosted gray underparts; its large, bulbous, and contiguous plantar pads; configuration of postorbital ridging; orientation of the zygomatic squamosal root, with its diagonal extension to the temporal ridge and not to the squamosal-exoccipital suture; slitlike incisive foramina; bony palate projecting well beyond the third molars to form a shelf with a smooth posterior margin; strongly diverging (along the anteroposterior axis) maxillary molar rows; expansive ectotympanic bulla concealing all but a short, narrow wedge of the periotic; distinct anterolabial cusps on second and third lower molars; and two roots that anchor each lower molar.

The differences enumerated above between Saxatilomys and Niviventer reflect a combination of primitive and derived features. Relative to the conformation in Niviventer, the contrasting condition in Saxatilomys is derived. Presence of anterolabial cusps on second and third molars, and number of roots beneath lower molars represent the primitive condition in Saxatilomys compared with the derived state in Niviventer.

COMPARISONS WiTH EXTINCT SPECIES: Fossil murines, represented mostly by isolated teeth, have been recovered from Pliocene, Pleistocene, and Holocene sediments in caves and limestone fissures in China, northern Vietnam, and Thailand. The bulk of the material is comprised of isolated molars, a few samples contain cranial and mandibular fragments. Some samples have been described as new taxa whose diagnostic traits indicate they are members of the Dacnomys Division, and other samples have been identified as examples of extant species of Niviventer. We surveyed a range of publications to determine whether any of the new taxa that are based on fossils represent examples of Saxatilomys, or whether any specimens determined to be living species of Niviventer may have been misidentified and are actually Saxatilomys. Only three reports are significant to our inquiry. In her treatise on the Plio-Pleistocene rodents of Thailand, Chaimanee (1998) described samples of isolated molars she identified as extant Niviventer fulvescens, and others she determined to be a new species, $N$. gracilis, that is apparently extinct. Judged from her descriptions, measurements, and illustrations, all these samples are correctly allocated to genus and species; lengths and breadths of molar rows are too small for $S$. paulinae.

Zheng (1993) reported his identifications of fossil murines recovered from late Pliocene and Pleistocene cave and fissure fillings. All come from the northern margin of the Yunnan-Guizhou Plateau between $104^{\circ}$ to $110^{\circ} \mathrm{E}$ and $26^{\circ}$ to $31^{\circ} \mathrm{N}$ in the provinces of Sichuan and Guizhou. Zheng documented those parts of the samples representing extant Niviventer fulvescens, $N$. confucianus, $N$. andersoni, and possibly $N$. excelsior; and the extinct $N$. preconfucianus. His descriptive and quantitative data, along with clear illustrations, provide unquestionable support for his identifications, particularly the extinct $N$. preconfucianus, which is clearly not the same as Saxatilomys.

Zheng (1993) also described three new species in two new genera that seem morphologically similar to Niviventer. Wushanomys brachyodus is represented by a large cranial fragment containing intact molar rows, dentary fragments with complete or partial molar rows, and numerous isolated maxillary and mandibular molars. The fossils come from sediments estimated to be no older than 2.5 million years, and no younger than 1.0 million years. A second species of Wushanomys, W. hypsodontus, is known from a few isolated molars. The time span of sediments from which the fossils were derived is 2.0 to 1.8 million years ago.

Zheng's other new genus and species, Qianomys wui, is based on a small series of dentary fragments containing full or partial molar rows, an isolated first lower molar, and two upper molars. These were recovered from sediments thought to be late Pleistocene, 400,000 to about 200,000 years ago.

We carefully compared our samples of Saxatilomys with Zheng's measurements of molar rows, isolated molars, and descriptions of cranial and mandibular fragments from Wushanomys and Qianomys. Molars of $S$. paulinae are too small, their occlusal surfaces too different, and their root pattern too dissimilar to be tied to either genus. Enough of the cranium of Wushanomys brachyodus 
is present to determine that it does not represent Saxatilomys.

Bacon et al. (2004) reported murines recovered from Pleistocene sediments in $\mathrm{Ma}$ U'Oi cave in northern Vietnam, south of Hanoi. One mandible containing a complete molar row was identified as Niviventer fulvescens, and an upper first molar and a lower first molar were attributed to $N$. andersoni. The molars were identified by comparing them with Chaimanee's (1998) treatise on fossil Plio-Pleistocene Thai rodents. Unfortunately, neither illustrations of molar occlusal patterns, or measurement values for the sample of $N$. fulvescens were provided by Bacon et al., and that identity cannot be verified. Of the two specimens determined to be $N$. andersoni, the first lower molar is probably from a species of Leopoldamys, but the identity of the first upper molar as $N$. andersoni cannot be substantiated using only the information in the report (Musser, Lunde, and Son, ms.). That first upper molar cannot be tied to Saxatilomys paulinae. Its breadth $(2.0 \mathrm{~mm})$ matches those values for $S$. paulinae (table 1$)$, but its length $(3.7 \mathrm{~mm})$ is too short (3.9 and 4.0 in the two examples of $S$. paulinae).

Fossils representing Saxatilomys paulinae likely lie undiscovered in Plio-Pleistocene sediments filling limestone fissures or buried deep beneath cave floors somewhere in Indochina, probably even in the Quy Dat limestone massif in the Khammouan region of Lao PDR and adjacent Vietnam. We cannot link Saxatilomys with any published descriptions of taxa based upon samples of fossils. While there is no nomenclatural concern, without fossils we have no record of either Saxatilomys's geographic distribution in the past (is it endemic to the Quy Dat massif, or did it once occur in other limestone island landscapes?), or the roots of its evolutionary history.

HABITAT AND HABITS: Meager ecological information is attached to the specimens of S. paulinae. AMNH 272953 and the holotype were caught by villagers using locally made traps known as loung, (as illustrated by Garrett, 1930: plate 16), fabricated entirely from bamboo and string, and baited with uncooked, husked, sticky rice. About 50 traps were set over three days on steep rocky slopes with a talus of large limestone boulders covered in heavily degraded deciduous forest mixed with scrub and bamboo at the base of the surrounding massive karst. Low places away from the limestone had been cleared for cultivation of paddy rice (figs. 1 , 2).

Habitats near the caves where the owl pellets were obtained from which fragments of $S$. paulinae were recovered are summarized as follows. Tam Jungvung: Heavily degraded deciduous forest mixed with scrub and bamboo occurred around the base of the karst. Low places away from the limestone had been cleared for cultivation of paddy rice. Tam En: Entrance to the cave is $200 \mathrm{~m}$ up the side of limestone. Vegetation immediately around the cave entrance consisted of thin deciduous forest mixed with cycads. The low-lying areas along the nearby River Hinboun were semievergreen forest with some of the larger trees already removed by local villagers, and small areas being cleared for cultivation of crops. Tam Key Thea: This cave was surrounded by heavily degraded deciduous and semievergreen forest mixed with bamboo. Many of the trees, particularly close to the village, had been removed and converted to building materials or fuel, or in low-lying areas to make way for rice paddies.

The regurgitated pellets from owls (a dead barn owl, Tyto alba, was found near the entrance to a cave) were found intact or in varying degrees of dissociation, usually at cave entrances, below roosting sites (Robinson and Webber, 1998). Remains below an owl roost may contain prey caught over several seasons, and is usually restricted to nocturnal species (Smith et al., 2004). Pellets containing remains of $S$. paulinae suggest that this rat is nocturnal, but does not identify the habitat from which they were caught by the owls. Whether $S$. paulinae actually lives inside cave entrances or only in forested talus outside the entrance and at the base of limestone towers needs to be resolved by careful ecological inquiries.

We are able to report that the diet of $S$. paulinae probably includes insects. Contents of the stomach of AMNH 272953 contained fragments of insect sclerites and legs mixed within an unidentifiable tan pulp. A pale 
whitish tan pulp containing definite minute fragments of insects, and some even smaller brown pieces that could be either insects or remnants from a brown seed coat was extracted from the stomach of the holotype. Contents from both rats had been thoroughly masticated. We saved the stomach contents so they could be examined with something more powerful than a dissecting microscope.

\section{CODA}

We suspect $S$. paulinae is petricolous. Large and bulbous plantar pads, along with a naked plantar surface, would provide traction on eroded limestone surfaces within a creviscular environment, the labyrinth of large and narrow passageways honeycombing the talus that consists of small to large limestone blocks. Dark gray pelage, while not a deterrent to owls, would render the rat nearly invisible against the dark limestone, and possibly provide concealment from other predators. Another possible petricolous small mammal caught in similar habitat in the same area is the gymnure, Hylomys megalotis (Jenkins and Robinson, 2002). Although no information is available concerning behavioral ecology for the species, Jenkins and Robinson (2002: 8) noted that certain morphological features of $H$. megalotis, “. . . such as the moderately broad forefeet with long, fairly stout claws, the long naked hindfeet with large cheridia [plantar pads], the moderately long tail and the comparatively flattened braincase may be adaptations to life [in karstian environments]." This gymnure also has gray fur. The hystricognath, Laonastes aenigmamus also possesses dark gray to grayish black pelage, long mystacial vibrissae, and very large, bulbuous pads on palmar and plantar surfaces (Jenkins et al., 2005). These morphological traits indirectly tie this special hystricognath to rocky habitats, even though the describers had no direct evidence that specimens were trapped in limestone talus or within caves.

That the novel gymnure, murid rodent, and hystricognath are members of a small mammalian ecological community restricted to forested, rocky habitats within an extensive and massive karst landscape seems a reasonable hypothesis to formulate from the exist- ing evidence. Other members of this unique group may be discovered. Currently, however, records of shrews (species of Crocidura and Suncus), tupaiid (Tupaia belangeri), squirrels (Callosciurus, Dremomys, Trogopterus, and Hylopetes), other murids besides S. paulinae (species of Mus, Rattus, Bandicota, Chiropodomys, Leopoldamys, Chiromyscus, and Berylmys), and a different hystricognath (the hystricid, Atherurus macrourus) obtained during the surveys in the Khammouan Limestone region (Robinson and Webber, 1998, 1999; Smith et al., 1998) reflect a fauna common to other parts of Indochina.

Other species of Indochinese murids live in forested, tropical karst regions but none have the morphological traits characterizing Saxatilomys paulinae. Two Thai murids are generally considered closely associated with limestone. Leopoldamys neilli is documented by a few specimens captured on the upper sections of forested limestone cliffs in Saraburi Province and adjacent Kanchanaburi Province in southwestern Thailand (Marshall, 1988; specimens in AMNH and USNM). Wiles (1981: 49), however, captured three individuals in lowland bamboo forest in a different part of Kanchanaburi Province, the trap sites averaged $115 \mathrm{~m}$ from the base of the nearest limestone mountain, and $L$. neilli was not encountered in the other habitat types Wiles surveyed, indicating the species to prefer lowland bamboo forest, which ". . . challenges the belief that $L$. neil$l i$ is strictly a cliff-dwelling rat."

Niviventer hinpoon is apparently endemic to the Korat Plateau in Saraburi Province of southern Thailand (Marshall, 1988; specimens in AMNH and USNM). One sample, which includes the holotype, was collected halfway up the face of a forested limestone cliff outside the entrance to a cave. Another series came from ". . . high above the valley floor, in scrubby vegetation at the base of vertical limestone cliffs. . " (Marshall, 1988: 459). Other species of murids were captured in the forested stream valley below the cliffs, but not $N$. hinpoon. Marshall (1988) also noted that one individual had been taken inside a limestone cave at a different locality. Whether $N$. hinpoon dens in clefts in cliffs or in talus is not recorded. Ex- 
cept for its tail, which is equal to or slightly longer than length of head and body, its buffy gray underparts, and its smaller body size (Marshall, 1988), the morphological traits of $N$. hinpoon closely resemble those of $N$. fulvescens, and multivariate analyses place it closer to $N$. fulvescens than to any other species (Musser and Lunde, ms.). Relative to palmar and plantar areas, the pads are no larger, no more swollen, or set no closer together than in $N$. fulvescens or most other species of Niviventer. Nothing in the morphology of $N$. hinpoon points to an obligate limestone cliff dweller. The dark gray and larger $S$. paulinae, with its relatively longer tail, large and bulbous plantar pads, and diagnostic cranial and dental traits is morphologically strikingly unlike $N$. hinpoon, even though $S$. paulinae is also associated with limestone habitats. Nothing comparable to the Lao PDR Saxatilomys has so far been found living in the karst landscapes of Thailand.

Karst landscapes cover only a small part of tropical Asia (Whitmore, 1984: 148). In Indochina they occur in southern China, north and central Vietnam, central Lao PDR, southern Cambodia, Thailand, and northeastern Burma (Middleton and Waltham, 1986; Zhang, 1989; Tuyet, 1998; also see the references cited in Whitmore, 1984). Outside the large limestone plateau in southern China, karstic landforms, especially massive tower karst, are small in area and scattered over Indochina as isolated geological islands (see distribution maps in Middleton and Waltham, 1986). Most have not been adequately sampled for small mammals. This is especially true for the eastern extension of the Quy Dat limestone massif into adjacent Vietnam (Binh Tri Thien Province). Results of surveys in the Khammouan portion of the Quy Dat massif, which yielded samples of Hylomys, Saxatilomys, and Laonastes, represent a first pass in revealing the diversity of small mammals, and their ecologies, in the Khammouan Limestone; the area deserves more detailed attention. The karst extension into neighboring Vietnam, however, is a blank, and demands intensive survey to determine if the unique Limestone fauna of the Khammouan region is also part of the Quy Dat massif in Vietnam. Careful surveys for small mammals in limestone landscapes elsewhere in Indochina would test the endemicity of the Khammouan Limestone gymnure and rodent community.

\section{ACKNOWLEDGMENTS}

The biodiversity survey of the Khammouan Limestone National Biodiversity Conservation Area was funded by the Global Environment Facility through the World Bank to the Lao PDR government, and from the Lao PDR government through a contract with Burapha Development Consultants subcontracted to WWF-Thailand. Vital support was received from the staff of the Lao PDR Department of Forestry. In particular, we thank Bouahong Phanthanousy, National Project Director of the Forest Management and Conservation Project (FOMACOP) for permission to work in Lao PDR and for organizing the Lao PDR component of the project, and Bouaphanh Phantavong (FOMACOP, Deputy National Project Director).

We also thank the staff of the World Wide Fund for Nature, Thailand, in particular Robert Mather (Lao PDR Biodiversity Project, Team Leader), Robert Steinmetz (Field Coordinator), and Bruce Jefferies (FOMACOP) for organizing and ensuring the smooth operation of the project.

We are grateful for Maurice Webber's help, vital in all aspects of the fieldwork. Also, assistance in the field was received from Thongphanh Ratanalangsy (Khammouan Limestone and Dong Phu Vieng NBCA Coordinator), Sinnasone Seangchantharong (Field Manager for Khammouan Limestone NBCA), Chainoi Sisomphone (DoF), and Nousine Latvylay (driver for FOMACOP in Savannakhet). Bruce Jefferies (FOMACOP) oversaw the export of specimens collected during the survey.

Paulina D. Jenkins (BMNH) kindly provided access to the mammal collection and loaned specimens to Musser at the American Museum of Natural History. We are indebted to her and all the other custodians of museum collections containing samples of Niviventer and Chiromyscus that, over the years, they allowed Musser and Lunde to study; much of that material formed a critical portion of our comparative samples. 
Patricia J. Wynne rendered the map and line drawings; all express her skill and attention to detail. Peter Goldberg is responsible for the photographic prints of skulls and molar rows. He again clearly transformed the three-dimensional specimen into a one-dimensional view accessible to all.

\section{REFERENCES}

Bacon, A.-M., F. Demeter, M. Schuster, V.T. Long, N.K. Thuy, P.-O. Antoine, S. Sen, H.H. Nga, and N.M. Huong. 2004. The Pleistocene Ma U'Oi cave, northern Vietnam: palaeontology, sedimentology and palaeoenvironments. Geobios 37: 305-314.

Berkmuller, K., S. Southammakoth, and V. Vongphet. 1995. Protected area system planning and management in Lao PDR: status report to mid 1995. Vientiane: unpublished report to LaoSwedish Forestry Co-operation Programme.

Brown, J.C. 1971. The description of mammals 1. The external characters of the head. Mammal Review 1: 151-168.

Brown, J.C., and D.W. Yalden. 1973. The description of mammals 2. Limbs and locomotion of terrestrial mammals. Mammal Review 3: 107134.

Bugge, J. 1970. The contribution of the stapedial artery to the cephalic arterial supply in muroid rodents. Acta Anatomica 76: 313-336.

Bugge, J. 1985. Systematic value of the carotid arterial pattern in rodents. In W.P. Luckett and J.L. Hartenberger (editors), Evolutionary relationships among rodents: a multidisciplinary analysis: 355-379. New York: Plenum Press.

Carleton, M.D. 1980. Phylogenetic relationships in Neotomine-Peromyscine rodents (Muroidea) and a reappraisal of the dichotomy within New World Cricetinae. Miscellaneous Publications Museum of Zoology, University of Michigan 157: 1-146.

Carleton, M.D., and G.G. Musser. 1984. Muroid rodents. In S. Anderson and J.K. Jones, Jr. (editors), Orders and families of Recent mammals of the world: 289-379. New York: Wiley.

Carleton, M.D., and G.G. Musser. 1989. Systematic studies of oryzomyine rodents (Muridae, Sigmodontinae): a synopsis of Microryzomys. Bulletin of the American Museum of Natural History 191: 1-83.

Chaimanee, Y. 1998. Plio-Pleistocene rodents of Thailand. Thai Studies in Biodiversity 3: 1303.

Fontaine, H., and D.R. Workman. 1978. Review of the geology and mineral resources of Kampuchea, Laos and Vietnam. Third Regional Conference on Geology and Mineral Resources of Southeast Asia, Bangkok, Thailand, 14-18 November, 1978: 540-603.

Fontaine, H., and D.R. Workman. 1997. In E.M. Moores and R.W. Fairbridge (editors), Encyclopedia of European and Asian regional geology: 774-782. Chapman and Hill: London.

Garrett, H.B. 1930. Notes on some traps made by the hill people of Siam. Journal of the Siam Society of Natural History, 8: 23-42.

Hershkovitz, P. 1962. Evolution of Neotropical cricetine rodents (Muridae), with special reference to the phyllotine group. Fieldiana: Zoology, Chicago Museum of Natural History 46: $1-524$.

Jenkins, P.D., and M.F. Robinson. 2002. Another variation on the gymnure theme: description of a new species of Hylomys (Lipotyphla, Erinaceidae, Galericinae). Bulletin of the Natural History Museum, London (Zoology) 68(1): 111.

Jenkins, P.D., C. William Kilpatrick, M.F. Robinson, and R.J. Timmins. 2005. Morphological and molecular investigations of a new family, genus and species of rodent (Mammalia: Rodentia: Hystricognatha) from Lao PDR. Systematics and Biodiversity 2(4): 419-454.

Jenkins, P.D., and M.F. Robinson. 2002. Another variation on the gymnure theme: description of a new species of Hylomys (Lipotyphla, Erinaceidae, Galericinae). Bulletin of the Natural History Museum, London (Zoology) 68(1): 111.

Lunde, D.P., and Nguyen Truong Son. 2001. An identification guide to the rodents of Vietnam. New York: Center for Biodiversity and Conservation, American Museum of Natural History.

Marshall, J.T., Jr. 1988. Family Muridae. In B. Lekagul and J.A. McNeely (authors), Mammals of Thailand, 2nd ed.: 397-487. Bangkok: Association for the Conservation of Wildlife, Saha Karn Bhaet Co.

Middleton, J., and T. Waltham. 1986. The underground atlas. A gazetteer of the world's cave regions. New York: St. Martin's Press.

Miller, G.S., Jr. 1912. Catalogue of the mammals of Western Europe (Europe exclusive of Russia) in the collection of the British Museum. London: British Museum (Natural History).

Musser, G.G. 1970. Species-limits of Rattus brah$m a$, a murid rodent of northeastern India and northern Burma. American Museum Novitates 2406: 1-27.

Musser, G.G. 1973. Species-limits of Rattus cremoriventer and Rattus langbianis, murid rodents of Southeast Asia and the Greater Sunda Islands. American Museum Novitates 2525: 165.

Musser, G.G. 1981. Results of the Archbold Expeditions. No. 105. Notes on systematics of 
Indo-Malayan murid rodents, and descriptions of new genera and species from Ceylon, Sulawesi, and the Philippines. Bulletin of the American Museum of Natural History 168: 225-334.

Musser, G.G. 1982. Results of the Archbold Expeditions. No. 110. Crunomys and the smallbodied shrew rats native to the Philippine islands and Sulawesi (Celebes). Bulletin of the American Museum of Natural History 174: 1-95.

Musser, G.G. 1991. Sulawesi rodents: Descriptions of new species of Bunomys and Maxomys (Muridae, Murinae). American Museum Novitates 3001: 1-41.

Musser, G.G., and M.D. Carleton. 2005. Superfamily Muroidea. In D.E. Wilson and D.M. Reeder (editors), Mammal species of the world: a taxonomic and geographic reference, 3 rd ed.: 894-1531. Baltimore: Johns Hopkins University Press.

Musser, G.G., and S. Chiu. 1979. Notes on taxonomy of Rattus andersoni and $R$. excelsior, murids endemic to western China. Journal of Mammalogy 60(3): 581-592.

Musser, G.G., and L.A. Durden. 2002. Sulawesi rodents: description of a new genus and species of Murinae (Muridae, Rodentia) and its parasitic new species of sucking louse (Insecta, Anoplura). American Museum Novitates 3368: 150.

Musser, G.G., and L.H. Heaney. 1992. Philippine rodents: definitions of Tarsomys and Limnomys plus a preliminary assessment of phylogenetic patterns among native Philippine murines $(\mathrm{Mu}-$ rinae, Muidae). Bulletin of the American Museum of Natural History 211: 1-138.

Musser, G.G., L.R. Heaney, and B.R. Tabaranza, Jr. 1998. Philippine rodents: redefinitions of known species of Batomys (Muridae, Murinae) and description of a new species from Dinagat Island. American Museum Novitates 3237: 151 .

Musser, G.G., and C. Newcomb. 1983. Malaysian murids and the giant rat of Sumatra. Bulletin of the American Museum of Natural History 174(4): 327-598.

Musser, G.G., A. van de Weerd, and E. Strasser. 1986. Paulamys, a replacement name for Floesomys Mussr, 1981 (Muridae), and new material of that taxon from Flores, Indonesia. American Museum Novitates 2850: 1-10.

Robinson, M.F., P.D. Jenkins, C.M. Francis, and A.J.C. Fulford. 2003. A new species of the Hipposideros pratti group (Chiroptera, Hipposideridae) from Lao PDR and Vietnam. Acta Chiropterologica 5(1): 31-48.

Robinson, M.F., and M. Webber. 1998. Small mammal survey: Khammouan Limestone $\mathrm{Na}-$ tional Biodiversity Area, Lao PDR. Unpublished report, World Wide Fund for NatureThailand, 1-48.
Robinson, M.F., and M. Webber. 1999. Further small mammal survey: Khammouan Limestone National Biodiversity Area, Lao PDR. Unpublished Report, World Wide Fund for NatureThailand.

Robinson, M.F., and M. Webber. 2000. Survey of bats (Mammalia: Chiroptera) in the Khammouan Limestone National Biodiversity Conservation Area, Lao P.D.R. Natural History Bulletin of the Siam Society 48: 21-45.

Smith, A.L., M.F. Robinson, and M. Webber. 1998. Notes on a collection of shrews (Insectivora: Soricidae) from Lao P.D.R. Mammalia, 62: 585-588.

Smith, A.L., M.F. Robinson, and M. Webber. 2004. Muridae (Rodentia) from the Khammouan Limestone and Xe Piane National Biodiversity Conservation Areas, Lao PDR. Mammalia 68(2-3): 167-173.

Thomas, O. 1919. The method of taking the incisive index in rodents. Annals and Magazine of Natural History, Series 9(4): 289-290.

Tuyet, Do. 1998. Overview on karst of Vietnam. In Yuan Daoxian and Liu Zaihua (editors), Global karst correlation: 179-192. Zeist, Netherlands: Science Press and VSP BV.

Voss, R.S. 1988. Systematics and ecology of ichthyomyine rodents (Muroidea): patterns of morphological evolution in a small adaptive radiation. Bulletin of the American Museum of Natural History 188(2): 259-493.

Voss, R.S. 1993. A revision of the Brazilian muroid rodent genus Delomys with remarks on "thomasomyine" characters. American Museum Novitates 3073: 1-44.

Wahlert, J.H. 1985. Cranial foramina of rodents. In W. P. Luckett and J.-1. Hartenberger (editors), Evolutionary relationships among rodents, a multidisciplinary analysis: 311-332. New York: Plenum Press.

Weerd, A. van de. 1976. Rodent faunas of the Mio-Pliocene continental sediments of the Teruel-Alhambra region, Spain. Utrecht Micropaleontological Bulletin. Special Publication 2: $1-218$.

Whitmore, T.C. 1984. Tropical rain forests of the Far East, 2nd ed. Oxford: Clarendon Press.

Wiles, G.J. 1981. Abundance and habitat preferences of small mammals in southwestern Thailand. Natural History Bulletin of the Siam Society 29: 44-54.

Zhang, S. 1989. Paleokarst of China. In P. Bosák, D.C. Ford, J. Głazek, and I. Horáčk (editors), Paleokarst, a systematic and regional review: 297-311. Amsterdam and Praha: Elsevier and Academia.

Zheng, S. 1993. [Quaternary rodents of SichuanGuizhou area, China]. Beijing: Science Press, $1-270$. 


\section{APPENDIX}

In assessing the morphological traits of Saxatilomys, we employed comparative samples of the following species of Niviventer and Chiromyscus.

$N$. andersoni $(N=18)$ : Southwestern China, Yunnan Province (AMNH 43274-43277, 43279, 43280, 43282-43288, 43290, 43291, 43293, 43295, 43296).

N. brahma $(N=3)$ : Northern Burma (AMNH 115216-115218).

N. cameroni $(N=19)$ : Malay Peninsula, Cameron Highlands (USNM 307602-307607, 311422, 311423, 489014-489024).

N. confucianus $(N=159)$ : China, western Sichuan Province (AMNH 111625, 111629, $111632,111633,111641,111646,111649$, $111650,111655,111659,111663,111668$, $111669, \quad 111671-111673,111675,111682$, $111685,111686,111688,111701,111725$, $111726,111736,111742,111748,111753-$ $111755,111757,111758,111764,111766$, 111767, 111769-111773, 111775-111777, 111781-111786, 111789, 111790, 111801, $111803,111805,111820,111822,111824$, 111838), western Yunnan Province (AMNH 43311-43314, 43319, 43325, 43329, 43338, $43341,43342,43345-43347,43350,43376$, $43380,43381,43383,43384,43386,43448$, $43449,43450,43452,43453,43458,43459$, 43461, 43462, 43468, 43469, 43470, 43473, 43475), and Fujian Province (AMNH 44587, 44603, 44604, 44606, 44610, 44611, 44615, $44617,45529,56705,56706,56708,56710$, $56713,60265,60288,60296,60297,60300$, $60301,60305,60309,60310,60312,60313$, 60315 , 84652-84654); Northern Vietnam, Lao Cai Province (FMNH 39245, 39247, 39251, 39252); Northern Burma (AMNH 113056, 113062-113065, 115167-115169, 115171, 115172, 115175-115177, 115179, 115180, $115184, \quad 115243, \quad 115199-115204 ; \quad \mathrm{BMNH}$ 15.5.5.230, 15.5.5.231, 15.5.5.232 (holotype of Rattus mentosus), 15.5.5.233-15.5.5.235, 15.5.5.237); Northern Thailand, Chieng-Mai Province (USNM 533399-533403).

N. coninga $(N=20)$ : Taiwan (AMNH 185160; USNM 294212, 311285, 311288-311291, 330290-330297, 333035, 333036, 333038, $333039,333289)$.

N. cremoriventer $(N=34)$ : Malay Peninsula (USNM 283551, 290222, 290223, 291289, $311427,311429, \quad 311435,488984-488988$, 488992); Borneo (103572, 103575, 103585, $103588,103589,103848,106121,106122$, $106208,106209,106210,106213,106216$, $106217,106219,106220,106221,106751$, 106758, 267736, 267726).
N. culturatus $(N=17)$ : Taiwan (USNM 261060 , 261061, 283762, 295127, 333047333052, 333054-333060).

N. eha $(N=18)$ : Northern Burma (AMNH 115210-115213, 115215, 115219-115231).

$N$. excelsior $(N=8)$ : Southwestern China, Sichuan Province (AMNH 113590-113594, 113602-113604).

N. fraternus $(N=16)$ : Sumatra, Gunung Dempo (AMNH 106335-106338, 106340-106344, $106346,106348,106349,106381,106656-$ 106658)

N. fulvescens $(N=275)$ : Nepal (HUNHM 7457-7459, 7461-7473, 7476-7481, 7483-7485, 7487, 7488; ZFMK 84.747, 84.750, 84.752, 84.755-84.759, 84.761-84.767); Northern Burma and Yunnan Province of China (AMNH 113042 $113045,113061,113048,115256,163697$, 163698, 163700-163702, 163711); China, Fujian Province (AMNH 44588, 44589, 44591-44595, 44598, 44599, 45524, 45526, 47895, 47900$47905,47910-47912,47915,47916,47919$, $47920,56719,56721,56726,56727,56730$, $56732,56734,56737,56738,56747,56750$, $56754,56755,60260,60261,60268,60269$, 60271, 60272, 60274); China, Hainan Island (AMNH 59031, 59054, 59068, 59071, 59072, 59078, 59135, 59146, 59151, 59196, 59238, 59243); Northern Vietnam, Lào Cai Province (FMNH 32003, 32004, 32007, 39193, 39198, 39201, 39204, 39205, 39207, 39209, 39214, $39215,39221,39225,39227,39232,39233$, 39236, 39242, 39246); Northern Vietnam, Hà Tinh Province (AMNH 272218, 272228, 272252, $272254,272257,272258,272287,272364$ $272366,272376,272393,272394,272396$, $272399,272406,272410,272414,272416$, $272428,272436,272451,272464,272466$, $272537,272551,272562,272621,272638$ ) [italicized numbers designate specimens deposited in the IEBR]; Southern Vietnam, Côn Èao (= Con Son Island or Pulau Condor; USNM 357208$357213, \quad 357215-357221, \quad 357223, \quad 357271-$ 357274); Northern Lao PDR (FMNH 32018, 32019 , 32022, 32023, 32025, 32020, 32031, 32032); Northern Thailand, Chieng-Mai Province (AMNH 167914-167918, 241661-241663, 242259-242261, 242263, 242270. USNM $355182,355188,355190,355192,355195$, $355196, \quad 355202, \quad 355698, \quad 533381-533384$, $533386, \quad 533503,553782, \quad 553784-553787$, 553873); Central Thailand, Ban Sakaret, Korat, Prachinburi, Nakon Ratchasima, Lampang, and Choliburi Provinces (AMNH 242271, 242273, 242275, 242276, 242280-242289); Peninsular Thailand, Ranong, Songkala, and Yala Provinces 
(AMNH 242290-242294, 242296, 242298; USNM 356751-356756, 356758, 356759); Peninsular Thailand, Koh Samui (AMNH 241656, 241657, 242295); Malay Peninsula, Perak State (USNM 311445-311447); Sumatra (AMNH 102808, 102809, 106350, 106351, 252176, 252762, 252763); Java (AMNH 103432, 103433, 250086, 250087, 252173, 252174, 252175; USNM 257622, 359667, 359668, 481607, 481608, 481610, 496968-496970, 521869, 521870); Bali (AMNH 107967-107969).

N. hinpoon $(N=15)$ : Thailand, Sariburi Province (AMNH 237576, 237577, 237579-237589, 242297, 250035).

N. langbianis $(N=49)$ : Northern Vietnam, Hà Tinh Province (AMNH 272147, 272156, 272160, 272166, 272178, 272194, 272197, 272202, 272204, 272205, 272207, 272208, 272209, 272222, 272236, 272245, 272247, 272248, 272249, 272251, 272459, 272460, 272461, $272262,272263,272265,272266,272267$, $272269,272289,272432,272437,272457$, $272468,272480,272481,272527,272528$, $272530,272531,272533,272536,272540$, 272546, 272549, 272553, 272555, 272591, 272637 [italicized numbers designate specimens deposited in the IEBR]).

N. lepturus $(N=16)$ : Java, Gunung Tjerimai (AMNH 102398-102409, 102410-102412, 102467).

N. niviventer $(N=27)$ : Nepal (HUNHM 74577459, 7461-7473, 7476-7481, 7483-7485, 7587, 7588).

N. rapit $(N=2)$ : Northern Borneo, Gunung Kinabalu (USNM 292781, 301083).

N. tenaster $(N=156)$ : China, Hainan Island
(AMNH 58970-58972, 58974, 58978, 58996, 59018-59020, 59036, 59042, 59045, 59194, 59195, 59299, 59302, 59293); Thailand, Chiengmai Province (AMNH 167920, 242265-242268; USNM 355183, 355184, 355186, 355187, 355189, 355193, 355194); Central Burma, Mount Victoria (AMNH 163707-163710, 163712$163715,163716,163718,163720,163721$, 163722 , 164724, 163726-163728, 163730163733); Southern Burma (northern peninsular Tenasserim; BMNH 88.12.1.53 [holotype of Epimys tenaster] 88.12.1.54); Southern Cambodia, Kâmpôt Province (FMNH 168678, 168679, $168681,168686,168689,168691,168692$, 168694, 168695, 168699-168702, 168709, $168710,168711,168712,168714,168717$, $168719,168721,168725,168726,168734-$ 168739, 168741-168744, 168746, 168747 , $168749,168750,168752,168755,168756$, 168758, 168762-168765, 168771-168773, $168775,168776,168779,168780,168783$, 168784, 168785); Northern Vietnam, Lao Cai Province (FMNH 39220, 39222-39224, 39226, 39229, 39234, 39331, 39235, 39237, 39243); Northern Vietnam, Hà Tinh Province (AMNH 272153, 272157, 272491, 272497). Southern Vietnam, Dac Lac and Lam Dong Provinces (BMNH 26.11.17.12 [holotype of Rattus bukit champa], 26.11.17.17-26.11.17.21; FMNH 46794, 46799, 46801, 46803, 46804; USNM $321438,321440,321442,321443,321446$, $321449,321450,321452,321453,321455$, $321457-321463, \quad 321467-321469, \quad 321473$, 321483, 321487.

Chiromyscus chiropus $(N=6)$ : Vietnam (AMNH 268333; BMNH 25.1.1.110, 26.10.4.167; FMNH 32010, 39269; MNHN 1929-298). 
Complete lists of all issues of the Novitates and the Bulletin are available at World Wide Web site http://library.amnh.org/pubs. Inquire about ordering printed copies via e-mail from scipubs@amnh.org or via standard mail from: American Museum of Natural History, LibraryScientific Publications, Central Park West at 79th St., New York, NY 10024. TEL: (212) 7695545. FAX: (212) 769-5009.

(2) This paper meets the requirements of ANSI/NISO Z39.48-1992 (Permanence of Paper). 